\title{
Multi-Criteria Hydro-Economic Decision Tool for Rejuvenating Community Irrigation Tanks in Rural India
}

\author{
Nicholas Charles ${ }^{1}$, Mahadev G. Bhat ${ }^{1, *(\mathbb{D})}$, Ramachandra Bhatta ${ }^{2}$, Krishna M. Hegde ${ }^{3}$ and Ganapati V. Hegde ${ }^{4}$ \\ 1 Earth and Environment Department, Florida International University, MM Campus, Miami, FL 33199, USA; \\ nchar042@fiu.edu \\ 2 College of Fisheries, Mangalore 575002, India; rcbhat@gmail.com \\ 3 Private Farmer, Bhairumbe, Sirsi 581402, Karnataka, India; krishnamhegde@gmail.com \\ 4 Department of Mines and Geology, Government of Karnataka, Bangalore 560001, India; hegdegv@gmail.com \\ * Correspondence: bhatm@fiu.edu
}

check for updates

Citation: Charles, N.; Bhat, M.G.;

Bhatta, R.; Hegde, K.M.; Hegde, G.V. Multi-Criteria Hydro-Economic Decision Tool for Rejuvenating Community Irrigation Tanks in Rural India. Water 2021, 13, 1594. https:// doi.org/10.3390/w13111594

Academic Editor: Krishna Paudel

Received: 13 April 2021

Accepted: 30 May 2021

Published: 5 June 2021

Publisher's Note: MDPI stays neutral with regard to jurisdictional claims in published maps and institutional affiliations.

Copyright: (C) 2021 by the authors. Licensee MDPI, Basel, Switzerland. This article is an open access article distributed under the terms and conditions of the Creative Commons Attribution (CC BY) license (https:/ / creativecommons.org/licenses/by/ $4.0 /)$.

\begin{abstract}
Rising water scarcity in agriculture has been a major concern worldwide. As resource managers seek to address this issue, Integrated Water Resources Management (IWRM) has become a widely accepted sustainability paradigm. The purpose of this study is to evaluate restoration alternatives of irrigation tanks by applying multi-criteria and probabilistic benefit-cost analysis for a rural watershed in India. We incorporate the principles of local-IWRM, namely, hydrological balance, efficiency, equity, stakeholders' involvement, and uncertainty. We use the mixed-method approach of data collection, including remotely sensed hydro-ecological data, walk-through field observations, focus groups, and household surveys. The study region produces a large percent of runoff water (i.e., about $67 \%$ of the total precipitation) which can be partially captured to sustain irrigation tanks. The majority of the tanks in the study area do possess moderate to high irrigation potential yet remain in poor conditions. A proposed lift irrigation scheme with a $75 \%$ or more increase in water availability could return from ₹ 1.23 to ₹ 1.73 on every Indian rupee (₹) invested, in addition to other socio-ecological benefits. The increase in water availability could lead to future crop area expansion, which comes with a high price tag. Therefore, using additional water on the existing crop area can be just as economically viable as water-induced crop expansion. A coordinated effort on the part of local agencies and water users is necessary for efficient and equitable use of incremental water that comes from any restoration efforts in the study area or elsewhere.
\end{abstract}

Keywords: IWRM; irrigation tanks; agriculture; multi-criteria; probabilistic benefit-cost analysis; runoff; India

\section{Introduction}

The growing human population puts increasing pressure on water demand. Against a fixed or declining supply, the increasing demand makes the water scarcity problem acute. The International Water Management Institute predicts that by 2025 approximately $78 \%$ of the world's population will face some degree of water scarcity. Developing countries, especially those with fast-growing populations, are facing water shortage problems more than ever. Agriculture is the single largest user of global freshwater, accounting for $70 \%$ of withdrawals (up to $90 \%$ in growing economies), and therefore, water shortage will have serious implications for food production and might force some of those countries to rely on food imports [1]. Water demand in developing countries is projected to be $27 \%$ higher in 2025 than in 1995, while the actual consumption of irrigation water is expected to fall short of this demand [2].

Ironically, the water crisis in agriculture is not solely due to declining water availability. More than $50 \%$ of the water extracted for agriculture is lost due to evaporation and wastage [1]. Both public and private water extraction and irrigation systems suffer significant inefficiencies, resulting in sub-optimal use of this scarce natural resource. 
Water wastage triggers more extraction. Excessive and inefficient allocation of water to agriculture and other sectors also compromises water available for the environment and the overall ecosystem health [3]. Additionally, access to irrigation water has not always been equitable in that the benefits of water resource investments in agriculture have not reached all producers in a fair manner [4,5]. Therefore, there is a growing interest in sustainable management approaches as a means to alleviating water scarcity and wastage and promoting agriculture development.

\subsection{IWRM Approach to Managing Agricultural Water}

Many developing countries have embraced Integrated Water Resources Management (IWRM) as a sustainable strategy for managing their water resources [6,7]. The Global Water Partnership defines IWRM as a process that "promotes the coordinated development and management of water, land and related resources, to maximize the resultant economic and social goal welfare in an equitable manner without compromising the sustainability of vital ecosystems." [8] At the core of the IWRM are the three sustainable development principles of social equity, economic efficiency, and ecological harmony.

While IWRM principles broadly apply to managing water resources at all spatial scales from large (multi-state) river basins to local-level watersheds, recent studies have shown that IWRM is more effective in managing small and local-level watersheds containing water bodies like minor irrigation tanks and groundwater aquifers $[9,10]$. This local IWRM can promote collaboration between local administrations, non-governmental organizations, and stakeholders. The participation of the local administration in water resource allocation allows for the local population to appreciate the immediate benefits of coordinated management more readily [7]. If designed and implemented correctly, such micro-level efforts may complement the goals of larger river basin level management. Oftentimes, managing water resources at the river basin level could be too complex to achieve due to lack of coordination among administrative agencies, lack of finance, and a variety of technological and socio-political reasons [11,12]. Applying IWRM principles at a smaller aquifer and watershed boundary is the first logical step to achieving water sustainability goals [7].

Implementing local-IWRM is not without its challenges. Resource managers and stakeholders often grapple with setting priorities between increasing surface and groundwater supply and reducing water demand [3]. The most common approach to dealing with water scarcity has been creating new water sources or storage while paying scant attention to demand-side management or existing water infrastructure. Augmenting the water supply itself may trigger increased wasteful and inefficient consumption of water. Only a limited number of progressive growers who have access to modern irrigation technology and capital may appropriate immediate benefits from an increased water supply. Past studies show that certain policies to promote irrigation efficiency (e.g., subsidies on irrigation equipment) have led to a "rebounding effect" or increased overall water consumption $[13,14]$.

Furthermore, the local property rights regime and customs may limit the local public agencies and institutions to make efficient decisions concerning allocation between users of surface water and groundwater [15]. Using the experience from India, the legal structure of water use governance is predominantly developed by each state. As a result, the absence of an overarching legal framework of water rights has led to a situation of varying rights to surface water and groundwater between localities. The development of these water rights has been directly influenced by India's colonial history, in which two major components of water ownership emerged: namely, state control over surface water bodies and private-use rights over groundwater. On the one hand, state and central governments have sought to make investments in age-old minor irrigation tank systems to increase surface water structure and storage, and in turn, to recharge underground aquifers. On the other, the Government of India and individual states and district administrations have taken many initiatives to introduce programs that support agricultural irrigation, such as subsidizing micro-irrigation and electricity-powered groundwater utilization by private farmers. Surface water bodies in many localities generally provide for public access with 
a variety of use rights, including surface irrigation, animal husbandry, washing, bathing, drinking, fishing, and environmental protection. Due to this differentiated property rights to surface water and groundwater, efficient allocation of these resources is difficult.

Historically, local water infrastructure decisions are made based on past observations of water supply and consumption patterns [3]. Benefits and costs of such decisions are evaluated using fixed parameters under the assumption that the underlying hydrological and economic systems are deterministic and that there is no variability in the occurrence of certain events. Past studies have recommended a probabilistic approach to evaluate system performances and decision making, recognizing that there is considerable variability in the future outcome owing to variability in climate, hydrology, and economic systems [16,17]. Resource managers are aware that future uncertainty in climate, economy, and technology may not follow historical patterns [3] and will require wider safety nets while handling future water shortages.

Finally, the success of local IWRM depends on the strength of local institutions and the effective coordination among multiple agencies and stakeholders. Transparency in the system operation and communication to stakeholders [6] and stakeholders' acceptance [7] are critical to achieving a desirable outcome for the local water management. Neither of these can be achieved without the full participation of stakeholders.

Despite the above natural complexities and socio-political challenges, local-IWRM remains to be a widely accepted sustainability paradigm. One of the first steps in operationalizing local-IWRM is to evaluate water resources projects from the lens of IWRM's sustainability principles. The main purpose of this paper is to illustrate how its philosophy and principles can be incorporated into traditional decision-support frameworks, such as multi-criteria analysis and benefit-cost analysis, for assessing local water resources investments.

\subsection{The Context of This Study}

This study focuses on minor irrigation tanks in India. Thousands of small surfacewater irrigation tanks are spread across the country's agricultural landscape. The system of irrigation tanks plays an essential role in sustaining India's food production $[18,19]$. Over centuries, these tanks have allowed farmers to meet agricultural water needs as well as their domestic needs. Irrigation tanks vary in size and comprise roughly $30 \%$ of the irrigated area in Southern India. These tanks often act as a chain to capture surface runoff through the system and eventually lead to rivers and streams [20]. These surface-water communal ponds were constructed hundreds of years ago and were linked through deep-seated societal, economic, and cultural norms in rural India [21].

In addition to providing direct irrigation benefits, tanks bring other direct socioecological benefits, including (a) acting as flood plains and sinks for excess rainfall and debris, (b) serving as a buffer for water during heavy drought periods, and (c) offering relief from stressed groundwater resources [22]. Furthermore, indirect benefits of tanks include increased opportunity for low-income individuals through the facilitation of drinking water as well as fish harvesting [23]. Therefore, the performance of these multi-purpose tanks directly influences people's livelihood by sustaining agricultural production, fisheries, livestock, and domestic water necessities [22,24]. The national and state agencies have begun to modernize some of these minor irrigation tanks and enhance their current irrigation potentials $[25,26]$. Researchers and public agencies are proposing two primary, location-specific approaches to restoring and enhancing the current system of minor irrigation tanks. The first approach is to remove silt from tanks. Siltation is the leading cause of tank degradation that reduces the water storage capacity to as little as 30\% [27]. Silt and other debris become confined in tanks through sedimentation in runoff, which reduces the active storage capacity. This problem can easily be addressed by de-silting the tanks usually in the dry season. The second approach to rejuvenating poor functioning irrigation tanks, as Kalle and Kasi [28] note, is to supplement them with water from external sources. Through what is called a lift irrigation scheme (LIS), one could mechanically lift water from streams, rivers, or other water bodies using pump systems and push it to higher elevation 
and then distribute the same to various irrigation tanks in the command area. Many rural agricultural districts throughout India do not have options other than LIS. In other parts of India, LIS has proven to be successful in enhancing irrigation potential when managed properly [29]. As Agoramoorthy et al. [29] report, such projects seem to have broader sustainability appeal in that they bring employment opportunities as well as increase crop production in rural areas.

Administrators at the state and district levels often grapple with the question of how to choose tanks for modernization (e.g., de-siltation or lift irrigation) with a limited budget. Studies have shown that the high cost of the de-siltation process makes it unviable in many scenarios. Inadequate government funding for restoration is often cited as a major challenge [30]. Additionally, the current process of choosing tanks solicits inputs from the village level governing body (i.e., Panchayat), local state legislative representatives, and community members. Although this allocative decision seems transparent and participatory, not all underlying hydrological and socio-economic factors receive due consideration in this process. Similarly, current financing of lift irrigation projects often lacks careful determination of hydrological limits on available water, project costs, project benefits, and other socio-economic distribution criteria. In other words, the above decision-making process often is not consistent with the local IWRM principles [8].

This study argues that the rejuvenation of a tank irrigation system-whether it is a small area consisting of a single tank or a larger network of multiple tanks-must follow a scientific and more comprehensive approach of IWRM to ensure that the traditional tank irritation systems contribute to local food security, socio-economic, and ecological improvements. Balasubramanian and Govindasamy [31] suggest that a performance-based ranking approach guides the decision to choose tanks for modernization. They find that factors such as cost of maintenance, water storage, and the existence of water users' associations must form the basis for restoration decisions. Along this line, our paper attempts to evaluate two specific objectives. The first objective is to develop a comprehensive and participatory method for prioritizing irrigation tanks for restoration using their hydrological, economic, and social attributes. This method involves incorporating multiple water resource attributes into a decision-support framework. Furthermore, these attributes reflect some of the IWRM's social, economic, and ecological sustainability principles. We first measure these attributes using both scientific data (e.g., hydrological, soils, land cover, and ecological) and socio-economic (e.g., food security, equity, and efficiency) data provided by local people. The measured values or performances of multiple attributes of any given tank are then aggregated by employing weights developed through the analytical hierarchy process (AHP) [32] and stakeholders' preference for each attribute. Multiple studies have used AHP to integrate stakeholder preferences and multiple-value indicators into a unifying tool to assess the sustainability of alternative technologies, management decisions, and conservation approaches [33-35]. Through this approach, we show that the adaption of multiple tank attributes and their composite values gives decisionmakers the ability to consider a host of ecological, economic, and political considerations while prioritizing communal tanks for modernization.

The second objective of the paper is to develop a hydro-economic methodology to scientifically evaluate the viability of a representative lift irrigation scheme based on IWRM's framework of efficiency, equity ecological sustainability, and resource user's participation [8]. Past studies on minor irrigation projects have employed the conventional benefit-cost analysis (BCA) tool to evaluate economic viability and equity considerations of alternative water allocation measures under a variety of climate-related uncertainty [36-39]. BCA tool has also been widely used in other fields of investment decisions, for instance, renewable energy resource projects [40-42] and transportation projects [43,44]. Most of the studies on water resources limited their analysis on the benefit side to estimates of the increase in water use, increase in crop yields, and likely increase in crop areas. In the present study, we develop rather a comprehensive benefit-cost framework that explicitly considers local hydrological limits, socioeconomics of agricultural productions, current and potential 
future water consumption behavior, and adoption of irrigation technology. We accomplish this by: (a) estimating regional runoff production and the maximum potential water that the stakeholders can exploit without hurting the ecological balance in the region; (b) adapting a production function that links increased water availability with the overall farmers and labor income, using primary household survey data; (c) utilizing data on stakeholders' water resource-use perception, and finally (d) using the usual engineering costs of project construction and maintenance. This approach is ecologically robust, economically sound, and stakeholder informed.

Furthermore, as mentioned before, the future performance of local water resources projects is highly uncertain. Following Yang et al. (2007) [43] and Khazraeian and Hadi (2018) [44], we consider multiple sources of uncertainty into the traditional BCA by expressing various model parameters as probability distributions instead of fixed values. The probabilistic BCA is conducted using the popular Monte Carlo simulation technique wherein the analysis is repeated with thousands of sets of parameters representing underlying variability over the life of the project $[45,46]$. The simulation helps generate project performance data and usual variability measures that are relevant to decisionmaking. We apply the model to a rural watershed in South India which is further delineated in the next section.

\section{Materials and Methodology}

\subsection{Study Area}

The study area consists of the watersheds of two adjacent Panchayats (smallest administrative units), namely Bhairumbe and Targod, covering about 10 villages and located between $14^{\circ} 41^{\prime} 29.69^{\prime \prime} \mathrm{N}$ and $74^{\circ} 46^{\prime} 57.78^{\prime \prime} \mathrm{E}$ in the central portion of the Western Ghats (Figure 1). The Western Ghats region has been hailed as one of the most prominent biodiversity hotspots in the world. Due to climate change and overexploitation of ecosystem services, conservation efforts in this area are becoming increasingly crucial [47]. The Western Ghats mountain range has experienced an almost $40 \%$ reduction of forest cover since the 1900s, and this reduction has been attributed to the national and regional policies that fuel agricultural development [48].

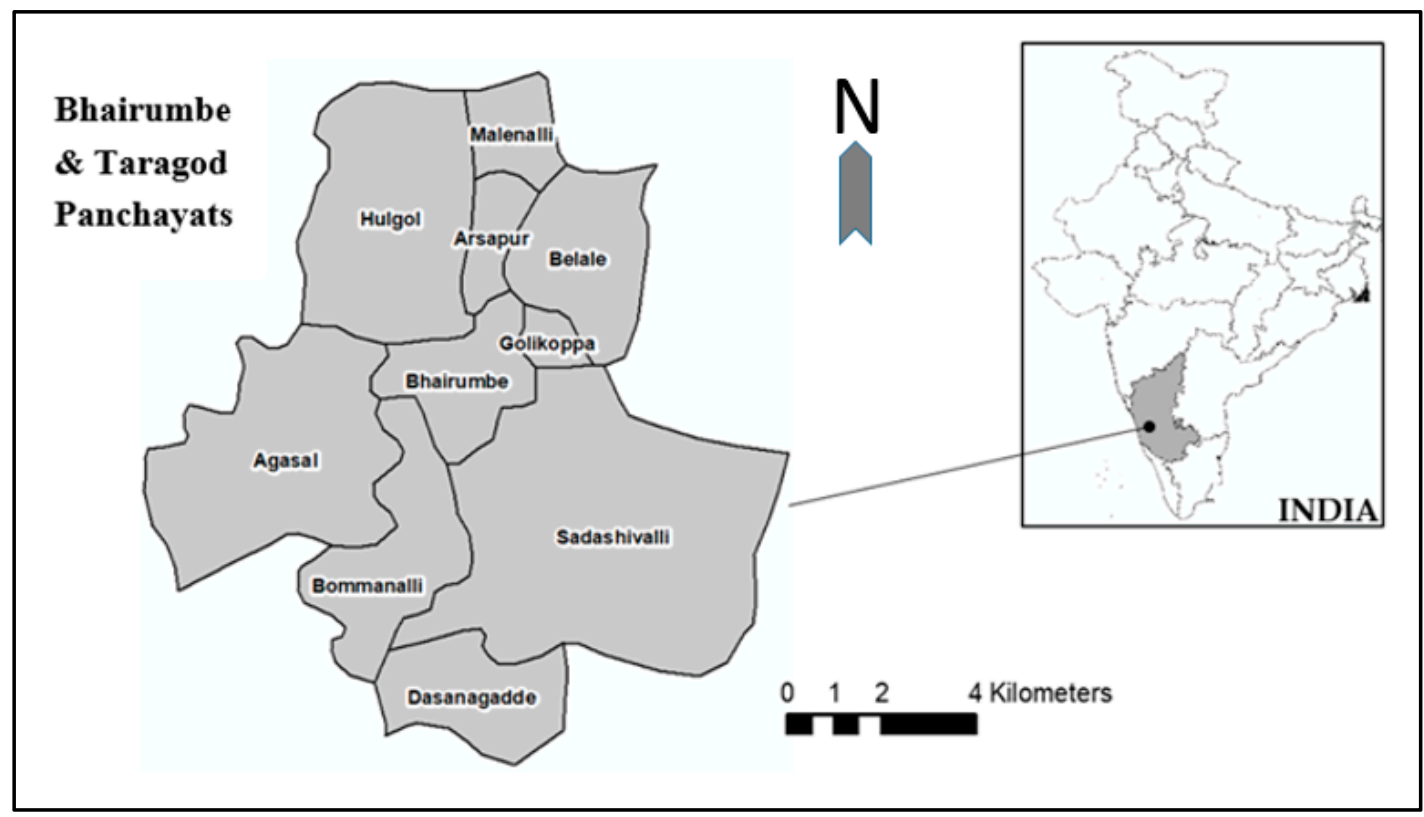

Figure 1. The study area map of the Bhairumbe and Targod Panchayat in Uttara Kannada District, India. (Source: authors).

The study panchayats consist of undulating topography with an elevation of roughly $609 \mathrm{mt}$ above sea level. It is a mountainous region formed by valleys and small hills with slopes ranging from gentle to moderate between a $4 \%$ and $15 \%$ gradient [49]. The soils in 
the study area consist of deep, well-drained, and moderately well-drained clayey soils on laterite planes, isolated hills, and valleys. There are seven different land covers in the study area. Of the total geographic area of $60 \mathrm{~km} 2,63 \%$ is covered by dense tree forests, $16 \%$ by areca nut, $7 \%$ by barren and fallow land, $3 \%$ by rice paddy, $4 \%$ by coconut, $5 \%$ by water, and $2 \%$ by urban area. The study villages rely on irrigation from tanks and the Shalmala River that meanders across the eastern border.

We base our research on a mosaic of irrigation tanks in a group of 10 villages of Bhairumbe and Targod Panchayats (panchayat $=$ smallest self-governing unit or local government) in the Uttara Kannada district of Karnataka, India. The irrigation tanks found in this study area are not being utilized to their fullest potential. The past $5-10$ years have seen a reduction in yields of staple crops such as rice paddy, coconut, areca nut, and banana primarily due to the fluctuating surface and groundwater reserves as well as erratic seasonal precipitation. Figure 2 presents examples of poor- and well-functioning tanks, respectively.

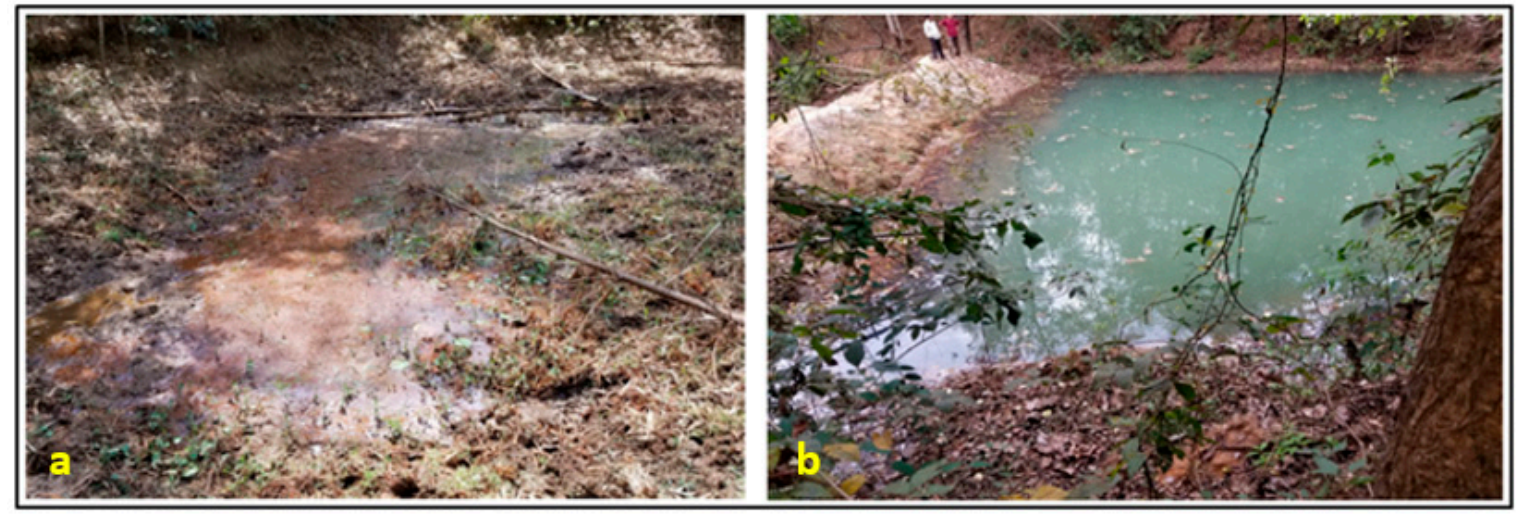

Figure 2. Status of representative minor irrigation tanks in the study area: (a) Keresara tank with high siltation and debris; (b) Devarakeri tank, newly de-silted, allowing for sheet flow and groundwater recharge. The majority of the tanks in the area are like the one in (a).

\subsection{Precipitation and Runoff Estimation}

In this study, we used remote sensing and GIS technology and the US Department of Agriculture's Soil Conservation Service - Curve Number (SCS-CN) model to accurately estimate the relationship between monthly precipitation, soil characteristics, land cover types, and the monthly runoff [50]. While the original model was developed by the US hydrological soil groups, researchers had used this methodology for various Indian watershed conditions with appropriate GIS and remote sensing data [51,52]. In this model, the total runoff $(Q)$ for a given watershed is given by

$$
Q=\frac{\left(P-I_{a}\right)^{2}}{\left(P-I_{a}\right)+S}
$$

where $P$ is the rainfall for the given duration, $S$ is the potential maximum soil moisture after runoff begins, and $I_{a}$ is the initial abstraction or the amount of water lost (e.g., due to infiltration) before the runoff begins. Furthermore, the parameter $S$ in the above model is given by the following equation:

$$
S=\frac{1000}{C N}-10
$$

where $C N$ is called the curve number, which varies between 30 and 100 depending on soil and land cover type and represents the maximum potential for runoff. For brevity, we refer the readers to Charles [53] for a detailed account of the methodology used for estimating the $C N$ numbers for various land classes and crop covers in the study site. Daily and monthly rainfall $(P)$ data from 2009-2017 come from the Government of Karnataka Water Resources Department. The elevation data and soil classification data necessary 
to compute $C N$ parameters came from India's National Remote Sensing Center and the Indian National Bureau of Soil Survey, respectively.

\subsection{Assessment of Minor Irrigation Tanks: Multi-Criteria Decision Approach}

The multi-criteria decision framework involves incorporating and measuring multiple attributes of a complex system and aiding with decision making. This is a powerful decision tool especially when many of the system's attributes are not quantified through monetary values [54]. Balasubramanian and Govindasamy [31] used this tool to cover the impacts of irrigation tanks on sustainability through environmental, social, and economic performances in India. Palanisami and Flinn [55], Zekri and Romero [56], Sakthivadivel et al. [22], and Verma [57] also used a similar methodology for water resources assessment. The first major step of this analysis is to choose the right performance indicators that best represent the contributions of a given system to social, economic, and hydrological aspects of the study area [58]. Based on the above studies and our discussions with key informants in the study areas, we included eight attributes relevant to the study area's socio-ecological system. This approach is consistent with a local-IWRM framework wherein researchers and local resource planners need to develop and apply metrics and methods suitable for local conditions [26]. For this reason, while specific results of this study may not be readily transferable to other areas, the overall approach should be scalable to broader water basins. See Table 1 for names, definitions, and assessment methods of the study attributes.

Table 1. Multi-attribute indicators that influence tank performance.

\begin{tabular}{|c|c|c|}
\hline Indicator & Description & $\begin{array}{c}\text { Units of } \\
\text { Measurement }\end{array}$ \\
\hline Tank Condition & $\begin{array}{l}\text { The overall effectiveness of tank for purposes of runoff capture, soil } \\
\text { erosion prevention, and sheet flow potential, based on visual assessment }\end{array}$ & Qualitative \\
\hline $\begin{array}{l}\text { Water-Holding } \\
\text { Capacity }\end{array}$ & $\begin{array}{l}\text { The current status of the size and depth of the tank, expressed in volume, } \\
\text { based on ArcGIS delineated area and key informant knowledge on depth }\end{array}$ & Quantitative \\
\hline Vegetation Health & $\begin{array}{c}\text { The overall health of vegetation on the shoreline and immediate } \\
\text { surroundings, based on visual assessment }\end{array}$ & Qualitative \\
\hline $\begin{array}{l}\text { Wildlife Habitat } \\
\text { Health }\end{array}$ & $\begin{array}{l}\text { Wildlife population size and species diversity within and around the tank, } \\
\text { based on visual assessment }\end{array}$ & Qualitative \\
\hline Potential Storage & $\begin{array}{l}\text { The potential volume of water of the tank if complete de-siltation measures } \\
\text { are taken, based on measurement of water-holding capacity }\end{array}$ & Quantitative \\
\hline $\begin{array}{l}\text { Access and } \\
\text { Convenience }\end{array}$ & $\begin{array}{c}\text { The degree of convenience for farmers and other individuals to easily } \\
\text { reach the tank, for religious, cultural, or maintenance purposes, based on } \\
\text { visual assessment and key informant knowledge }\end{array}$ & Qualitative \\
\hline Crop Acreage Irrigated & $\begin{array}{l}\text { Acreage of land that is irrigated directly through surface runoff and flow } \\
\text { accumulation, based on delineated catchment areas from ArcGIS and land } \\
\text { cover map }\end{array}$ & Quantitative \\
\hline Usability & $\begin{array}{l}\text { The potential for farmers and other individuals to utilize the tank as an } \\
\text { alternative source of food/income, based on visual assessment and key } \\
\text { informant knowledge }\end{array}$ & Qualitative \\
\hline
\end{tabular}

We visited 40 out of 45 minor irrigation tanks that were spread across the study area during January and February in 2018. Most of the tanks are recharged by rain or through rain-fed runoff, with some exceptions that were fed by the Shalmala River. All the chosen tanks were owned by the State Government and overseen by its Minor Irrigation Department. The qualitative attributes (Table 1) were measured through firsthand observations during our walkthrough around each tank along with key informants during January and February of 2018. We applied a valuation rubric for each qualitative indicator using a scale from one to five, where one represents the lowest performance and five represents the highest performance. The quantitative attributes are measured using estimates of water runoff at each tank level using the same methodology described in the previous section on precipitation and runoff. 
The current water-holding capacity attribute for each of the tanks required finding the area of the tank and average depth. The area of the tank was measured by mapping out each irrigation tank in a projected coordinate system in ArcGIS and using the "Calculate Geometry" function. Key informants in each village had provided information on the average depth of each irrigation tank during the peak dry season and peak wet season. These averages were used as the maximum and minimum depth for the tanks for high-depth months (September and October) and low-depth months (April and May), respectively, on a trend line. We extrapolated the depth during the survey month (January or February) from this trend. Multiplying the area of the tank and the estimated average depth for the study month yielded the amount of water-holding capacity. Potential storage capacity is the maximum potential storage of the tank based on its individual surface area and depth. Finally, the attribute for acreage irrigated was developed using ArcHydro tools in ArcGIS software [59].

To use the performance indicators to compare between tanks, we normalized original values on a common scale from 0 to 10 using the following equation [20,21]:

$$
I_{n, j}=\frac{I_{n, j, a}-I_{j, \min }}{I_{j, \max }-I_{j, \min }}
$$

where $I_{n, j}$ is the normalized value for tank $n(n=1,2, \ldots, 40)$ and indicator $j(j=1,2$, $\ldots, 8)$; and $I_{n, j, a}, I_{j, m i n}$, and $I_{j, m a x}$ are the actual, minimum, and maximum possible values of indicator $j$, respectively. Furthermore, realizing that the eight indicators might not carry equal significance or importance in the minds of various stakeholders, we employed the Analytic Hierarchy Process (AHP) [32] to develop weights of each indicator. Past studies have developed alternative approaches to finding criteria/indicator weights in multi-criteria decision analysis (MCDA). Rezaei (2015) [60] presents the best-worst criteria comparison method for developing weights, while Odu (2019) [61] reviews eight different subjective and objective weighting techniques. We opted for AHP as this was a commonly known weighting technique used in MCDA. The process required consulting local key informants or experts that were knowledgeable about the area. Following Krajnc and Glavič [35], we obtained the weights of indicators by taking a consensus of expert farmers and scientists using a pair-wise comparison method. Informants were asked to compare two indicators at a time to each other in terms of the intensity of preference on a scale from 0 to 9 .

After computing normalized values and weight values, the next step is to compute the Composite Index (In) for each tank based on eight original indicators. This index provides a real number representing the overall environmental and socio-economic condition of a tank. The index also represents the three dimensions of sustainability: economic, environmental, and social, to properly assess the current sustainability condition of a given tank [33]. Formally, the composite index is computed by,

$$
I_{n}=\sum_{j=1}^{8} W_{j} I_{n, j} \quad \text { for } n=1,2, \ldots, 40 .
$$

where $W j$ is the weight of indicator $j$ developed through the AHP and the pair-wise comparison of all eight indicators by stakeholders.

The composite indices computed above should serve as a basis for ranking irrigation tanks for restoration purposes. The tanks with higher composite values represent higher overall sustainability outcomes. A limited amount of each year's budget would be distributed to the highest valued tanks each year till funding lasts. However, we caution that sometimes the preference of local stakeholders and state and national agencies may vary [34]. For instance, one might argue that tanks with lower current composite value deserve more immediate restoration intervention. The resource agency may prefer to apply a cost-effective approach by trying to maximize the number of irrigated acres supported for every million rupees invested in the restoration effort. Alternatively, on strict IWRM 
equity and national food security considerations, the agency may prefer to maximize the number of irrigated rice acres per million restoration rupees invested. However, in this study, we chose to report the ranks based overall composite sustainability index, while we also reported the values of other indicators.

\subsection{Household Water Consumption and Perception Survey}

To understand the current water consumption and people's perception of water availability in the study area, we conducted a primary survey of 200 households. We followed a stratified random sampling method in which we strived to survey between $20 \%$ and $30 \%$ of households in each of the 10 villages. The survey collected socioeconomic attributes such as household demographics, irrigation, agricultural water use, educational level, land holdings, water use for different crops, the extent of water scarcity, and the resulting loss of crops in recent years. The survey also provided information on the farmers' perceptions of the status of available water resources in the area, the proposed lift irrigation project, the potential use of such projects, and the likely impacts of increased water availability on future cropping patterns.

\subsection{Benefit-Cost Analysis of the Lift Irrigation Scheme}

The section presents the hydro-economic methodology we used to scientifically evaluate the viability of a representative Lift Irrigation Scheme (LIS). The Karnataka State Minor Irrigation Department was considering an LIS for the study area. The project would involve building a dam across the Shalmala river, lifting water during the rainy season from the river to a mountaintop storage tank and delivering water through a network of conveyance to 10 minor irrigation tanks during the dry season. It was expected that additional water supplied to these tanks during the dry season would recharge wells and open streams in and around the respective command areas, and in turn, result in increased agricultural production as well as provide other non-consumptive benefits.

The actual increase in the available water due to the proposed project depends on a variety of factors such as natural availability of river water, regulatory restrictions on extraction and storage, institutional norms on the allocation of water to individual irrigation tanks, etc. There were no such rules or norms available as the project was still going through the budgetary approval process. Following Goel and Kumar [38], we first computed the pro rata runoff volume produced by the catchment area of the 10 affected tanks based on the ratio of the tanks' catchment area relative to the area of the entire study villages. We then assumed that the water that would be lifted from the river should not exceed the estimated runoff from the tank's catchment area.

Using the ArcGIS and land cover map developed in the previous section, we estimated the current acreage of different crops under the command areas of each affected tank. Based on the household survey and the current market data, we further estimated per acre yields for various crops in the command area, e.g., areca nut, coconut, banana, black pepper, and fruit crops. The average crop prices for 2017 were available from the Department of Agricultural Marketing and Karnataka State Agricultural Marketing Board. The total household agriculture revenue for the command area was calculated by multiplying area, yield, and estimated output prices.

The next step involved estimating the functional relationship between water use and agricultural revenue $[19,38,46]$. The Cobb-Douglas production function has been widely used in economics literature to capture the relationship between production inputs and output [62-64]. We assumed that water and land were the two major variables that determined household agricultural revenues, while all other inputs were applied in a fixed proportion. Since households grew a variety of crops and it was hard to estimate production function for each crop separately due to lack of data, we expressed all agricultural outputs in their monetary values and aggregated for each household. Formally, the total annual household agricultural revenue was assumed to follow the following Cobb-Douglas production function:

$$
G=\propto W^{\beta_{1}} L^{\beta_{2}}
$$


where $G, W$, and $L$ are amounts of annual household agriculture revenue, annual irrigation water consumed by the household, and land area in agriculture, respectively; $\alpha$ is the intercept parameter; and $\beta_{1}$ and $\beta_{2}$ are the revenue elasticity parameters. We added a third variable, called Areca Dummy (A), to capture the effects of qualitative differences between households with areca crop and households without. We hypothesized that households who had the majority of their farmland under areca orchard had higher annual income than those who did not. Variable A is assigned a value of "1" if a sample household had more than $50 \%$ of the land under the areca crop, and a value of " 0 " otherwise. The variables in Equation (5) were expressed in their natural log forms. The advantage of this double-log production function is that the estimated slope parameters are the estimates of the elasticities of the revenue variable concerning $W$ and $L$. The final estimating equation was expressed as,

$$
\ln G=\ln \alpha+\beta_{1} \ln W+\beta_{2} \ln L+\beta_{3} A+\varepsilon
$$

where $\varepsilon$ is the error term.

The data for water, land area, and areca dummy were derived from the household survey. We gathered information on the number of irrigation pumps, the main use, horsepower, average hours of use per week, and the number of months of use per year. The total annual extraction of water in liters per household was then derived from this information. Finally, each respondent's area of cropland in acres was also collected through this survey.

We considered three conservative scenarios of increased irrigation water use from the lift irrigation project in the catchment: (1) $50 \%$ increase from the current water consumption, (2) $75 \%$ increase, and (3) $100 \%$ increase. Each of the above three scenarios fell within the total annual runoff calculated for the ten-tank catchment area. Furthermore, the above increases are within the current range of water use. For instance, an average 75\% increase in annual water consumption is equivalent to the 80th percentile of the current annual water consumption. Therefore, the above water-use increase scenarios are within the feasible range. Additionally, we also considered three land area scenarios. The household survey had revealed that with the LIS, at least $82 \%$ of the privately held bena (grass) land would be converted to agricultural crops. Therefore, we considered three crop area expansion scenarios: (1) no expansion in crop area; (2) conversion of $82 \%$ of bena land into crops; and (3) conversion of $50 \%$ of bena land into crops.

Using the estimated water and land elasticities of agricultural revenue, we calculated the incremental gross agricultural revenue $(\Delta G)$ for the entire LIS command area under each of the above $3 \times 3$ water-crop expansion scenarios, using the following expression:

$$
\Delta G=\beta_{1}\left(\frac{G}{W}\right) \Delta W+\beta_{2}\left(\frac{G}{L}\right) \Delta L
$$

Finally, from the above incremental gross revenues, we subtracted the estimated costs of production to obtain incremental net agricultural revenues for each water-use scenario.

For benefits $(B t)$, we considered two types of incremental benefits from increased water use: (a) increase in household agricultural net income and (b) increase in wage income for farmworkers. An increase in the annual net agricultural income or incremental profit due to the project was taken as a percentage of the total incremental agricultural revenue $(\Delta G)$ (as in Equation (7)). The data on the percent of profit was available from Patil et al. (2016) [19]. Equity is an important consideration for the local-IWRM. Therefore, the additional income accruing to farmworkers who generally fell within the low-income category was viewed as an important equity consideration of the project. Farmworkers income was set at a random proportion of total annual incremental income $\Delta G$.

On the cost side, we considered the usual initial costs of commissioning the LIS as well as the costs of de-silting the 10 irrigation tanks in the area. The logic was that without the restoration of those tanks, the proposed additional water extracted would not be properly stored during the dry season. Additionally, we included another cost item in consideration of equity for low-income farmers. The household survey revealed that only 
$45 \%$ of the farmers did have irrigation equipment in the study area. Low-income farmers who did not have modern irrigation equipment would not fully utilize underground water post-LIP. Therefore, in the initial establishment cost, we included the costs of installing irrigation technology on an additional $45 \%$ of the command area, thus doubling the total area equipped with irrigation technology. The irrigation costs also included appropriate interest on private loans to farmers. The initial construction costs $\left(C_{t}\right)$ were divided into the first three years, and then operating costs were considered for the entire life of the project, i.e., year 4 through year 50 . Furthermore, appropriate costs of establishing new croplands were considered under the possible scenarios that a portion of bena land (grassland) would be converted to crops post LIS. The cost information was gathered from the Karnataka Minor Irrigation Department or directly from key informants in the study area.

The economic viability of the project was assessed using the three most popular financial measures of capital investment: benefit-cost ratio (BCR), net present value (NPV), and payback period (PBP). The BCR measures the total amount of incremental dollar return on every dollar invested, in current dollar terms, during the life of the project. The NPV measures the difference between total incremental return and total costs, both in present dollar value. For the project to be viable under a given scenario, the $\mathrm{BC}$ ratio must be greater than or equal to one, and the NPV must be greater than or equal to zero. For both measures, the future benefits and costs are discounted to present values using the standard social discount rate of $r=5 \%$ Formally,

$$
\begin{gathered}
\text { BC Ratio }=\sum_{t=1}^{50} \frac{B_{t}}{(1+r)^{t}} / \sum_{t=0}^{50} \frac{C_{t}}{(1+r)^{t}} \\
\mathrm{NPV}=\sum_{t=1}^{50} \frac{B_{t}}{(1+r)^{t}}-\sum_{t=0}^{50} \frac{C_{t}}{(1+r)^{t}}
\end{gathered}
$$

where $B_{t}$ is the annual incremental benefit of in period $t=1,2, \ldots, 50$. The initial costs of the irrigation project are $C_{0}$, and the annual maintenance and operational costs are $C_{t}$ $(t=1,2, \ldots, 50)$. We assumed that the economic life of the proposed project would be $T=50$ years. The third financial decision criterion PBP was computed as the number of years within which the initial investments would be fully recovered. We conducted the incremental benefit-cost analyses for all the nine combinations of water-land scenarios.

\subsection{Monte Carlo Simulation}

To account for different sources of hydrological, production, and market uncertainties, several of the variables and parameters in the above models were treated as stochastic variables. Some of the variables were expressed as a normal distribution with estimated mean and standard deviation. For instance, incremental annual agricultural revenue $(\Delta G)$ was computed as a random variable for each year of the project life by imposing normal distributions on the water and land elasticities $\left(\beta_{1}\right.$ and $\left.\beta_{2}\right)$ as well as the current annual agricultural revenue $(G)$ in Equation (7). The mean and the SDs of these normal distributions were estimated from the household sample data. Other parameters such as proportions of farmers' and farmworkers' income, costs of irrigation, and annual operating costs were assumed to follow uniform distributions with appropriate minimum and maximum values. These parameter ranges were determined after consulting with key informants in the study area. See Table 2 for various stochastic parameters used for the Monte Carlo simulation.

We performed 5000 Monte Carlo simulations of each of the nine water-land scenarios on Excel with as many sets of model variables and parameters generated from random distributions. The results of each simulation were saved to generate distributions of incremental incomes, BCR, NPVs, and PBP. We then computed the usual statistics of these distributions (mean, $\mathrm{SD}$, and percentiles) and compared the results across various scenarios. 
Table 2. Variables and parameters used in the probabilistic benefit-cost analysis.

\begin{tabular}{|c|c|c|c|}
\hline Variable/Parameter & Fixed or Random & Unit & Values \\
\hline Current cropland ${ }^{1}$ & Fixed & acre & 201 \\
\hline Crop area expansion ( $82 \%$ bena land $)^{2}$ & Fixed & acre & 67.4 \\
\hline Crop area expansion ( $50 \%$ bena land $)^{2}$ & Fixed & acre & 41.1 \\
\hline Current agriculture revenue $(G)^{2}$ & Normal distribution & ₹/acre/year ${ }^{3}$ & Mean $=245,879 ; \mathrm{SD}=129,892$ \\
\hline Current water consumption $(W)^{2}$ & Fixed & cubic meter & $1,727,179$ \\
\hline Water elasticity of Agri revenue 2 & Normal distribution & - & Mean $=0.5176 ; \mathrm{SD}=0.2977$ \\
\hline Land elasticity of Agri revenue 2 & Normal distribution & - & Mean $=0.2320 ; \mathrm{SD}=0.6759$ \\
\hline $\begin{array}{l}\text { The proportion of farmers' profit in total } \\
\text { agriculture revenue }\end{array}$ & Uniform distribution & $\%$ & Between 40 and 50 \\
\hline $\begin{array}{l}\text { The proportion of labor income in total } \\
\text { agricultural revenue } 4\end{array}$ & Uniform distribution & $\%$ & Between 20 and 25 \\
\hline The initial construction cost of LIP 5 & Fixed & $₹$ & 90 million \\
\hline Restoration cost of irrigation tanks ${ }^{6}$ & Fixed & $₹$ & 3.2 million \\
\hline $\begin{array}{l}\text { Installation of irrigation structure on } 45 \% \\
\text { of the existing cropland } 6\end{array}$ & Fixed & $₹$ & 18.1 million \\
\hline $\begin{array}{c}\text { Annual operating cost as a percent of } \\
\text { initial construction cost }{ }^{5}\end{array}$ & Uniform distribution & $\%$ & Between 2 and 4 \\
\hline Cost of establishing crops on grassland ${ }^{6}$ & Fixed & $₹ /$ acre & 0.35 million \\
\hline Discount rate ${ }^{7}$ & Fixed & $\%$ & 5 \\
\hline
\end{tabular}

${ }^{1}$ Estimated using ArcGIS and land cover map; ${ }^{2}$ estimated from the household primary survey; ${ }^{3}$ one Indian $₹$ (rupee) $=$ US $\$ 0.0147$ in 2018; ${ }^{4}$ Patil (2016) [19]; ${ }^{5}$ Karnataka Department of Minor Irrigation; ${ }^{6}$ key informant interview; and ${ }^{7}$ standard rate of real interest.

\section{Results}

\subsection{Precipitation and Runoff Estimates}

Between 2009 and 2017, the study area received an annual average rainfall of 2298 $\mathrm{mm}$. However, the rainfall significantly varied from a low of $1428 \mathrm{~mm}$ in 2016 to a high of $2868 \mathrm{~mm}$ in 2017. In May, on average, only $17 \%$ of the rainfall resulted in surface runoff, while the remaining amount gets distributed between evapotranspiration and infiltration. However, for June through September, over $50 \%$ of the average rainfall resulted in surface runoff. The average annual runoff was approximately $66.9 \%$ of the total average annual rainfall. This estimate is more conservative than the previous estimates for other parts of the region, for which the estimated monthly runoff in the monsoon season ranged between $70 \%$ and $90 \%$ [51]. The above runoff number for the area is an indication that there is potential for capturing some of this water balance to increase water resources for farmers. This information is quite useful for water and land management decisions, including effective siting for implementation of terraces, diversion of stream channels, irrigation tanks, and recharge trenches [52].

\subsection{Conditions of Minor Irrigation Tanks}

Table 3 presents the performance of the irrigation tanks in terms of various indicators. The tanks had a diverse range of surface areas ranging from 69.9 to $14,022 \mathrm{~m}^{2}$. This large variation was a result of the siltation buildup from runoff, the encroachment of agricultural land, and the age of the individual irrigation structure. The larger tanks not only had a much higher water-holding capacity but also seemed to be in a more ecologically healthy state. 
Table 3. Performance indicator values of irrigation tanks in the study area.

\begin{tabular}{|c|c|c|c|c|c|c|c|c|c|c|c|}
\hline Tanks & $\begin{array}{c}\text { Surface } \\
\text { Area } \\
\left(\mathrm{m}^{2}\right)\end{array}$ & $\begin{array}{c}\text { Tank } \\
\text { Condition }\end{array}$ & $\begin{array}{c}\text { Water- } \\
\text { Holding } \\
\text { Capacity } \\
\text { (Acre-foot) }\end{array}$ & $\begin{array}{c}\text { Vegetation } \\
\text { Health }\end{array}$ & $\begin{array}{c}\text { Wildlife } \\
\text { Habitat } \\
\text { Health }\end{array}$ & $\begin{array}{c}\text { Potential } \\
\text { Acreage } \\
\text { Irrigated }\end{array}$ & $\begin{array}{c}\text { Access } \\
\text { and } \\
\text { Convenience }\end{array}$ & Usability & $\begin{array}{l}\text { Potential } \\
\text { Storage } \\
\text { (Acre-foot) }\end{array}$ & $\begin{array}{c}\text { Ratio of } \\
\text { Current to } \\
\text { Potential } \\
\text { Storage (\%) }\end{array}$ & $\begin{array}{c}\text { Estimated } \\
\text { Cost of } \\
\text { De-Siltation } \\
\text { (Million ₹) }\end{array}$ \\
\hline Gadigehole & 713.5 & 2 & 0.97 & 2 & 1 & 6 & 1 & 1 & 1.41 & 69 & 0.106 \\
\hline Bugadimane & 1040.7 & 4 & 4.7 & 2 & 2 & 53 & 2 & 3 & 9.41 & 50 & 0.154 \\
\hline Kibbali & 219.3 & 4 & 1.16 & 4 & 4 & 30 & 2 & 4 & 1.87 & 62 & 0.033 \\
\hline Ashimane & 631.3 & 5 & 1.16 & 5 & 5 & 9 & 2 & 4 & 1.87 & 62 & 0.094 \\
\hline Halige & 831.9 & 4 & 0.82 & 3 & 3 & 4 & 5 & 3 & 1.02 & 80 & 0.123 \\
\hline Devari Keri & 1384.4 & 5 & 4.78 & 5 & 4 & 7 & 4 & 5 & 4.78 & 100 & 0.205 \\
\hline Appurayanajaddi & 4313.8 & 3 & 10.65 & 4 & 3 & 4 & 2 & 2 & 21.31 & 50 & 0.640 \\
\hline Hakkimane-1st & 1224.5 & 3 & 0.75 & 3 & 4 & 8 & 3 & 2 & 1.51 & 50 & 0.182 \\
\hline Hakkimane-2nd & 2024.6 & 2 & 1.25 & 4 & 2 & 25 & 4 & 4 & 2.5 & 50 & 0.300 \\
\hline Emme & 4784.6 & 4 & 3.54 & 5 & 4 & 12 & 5 & 5 & 7.09 & 50 & 0.710 \\
\hline Jaanamaki & 7118.2 & 4 & 15.83 & 5 & 5 & 21 & 5 & 3 & 26.38 & 60 & 1.056 \\
\hline Chowdi-1st & 2906 & 1 & 7.8 & 2 & 2 & 4 & 5 & 4 & 12.92 & 60 & 0.431 \\
\hline Malenalli & 1859.4 & 2 & 1.83 & 3 & 2 & 10 & 5 & 1 & 3.67 & 50 & 0.276 \\
\hline Arsapura & 1439.1 & 1 & 2.66 & 4 & 4 & 5 & 2 & 2 & 5.33 & 50 & 0.214 \\
\hline Nagarakura & 2714.2 & 3 & 8.38 & 2 & 2 & 30 & 2 & 1 & 13.41 & 62 & 0.403 \\
\hline Keresara & 462.9 & 4 & 0.57 & 3 & 2 & 8 & 5 & 4 & 1.14 & 50 & 0.069 \\
\hline Targod & 9509.4 & 5 & 21.14 & 5 & 4 & 43 & 5 & 3 & 35.24 & 60 & 1.411 \\
\hline Ambalike & 5374 & 4 & 7.3 & 5 & 5 & 35 & 4 & 5 & 9.29 & 79 & 0.798 \\
\hline Kathlehalla & 14022 & 3 & 19.05 & 3 & 5 & 51 & 3 & 2 & 34.64 & 55 & 2.081 \\
\hline Nidagod & 2396.5 & 3 & 2.96 & 4 & 3 & 15 & 1 & 1 & 3.55 & 83 & 0.356 \\
\hline Anchigadde & 1313.4 & 3 & 2.75 & 2 & 2 & 14 & 2 & 2 & 4.86 & 57 & 0.195 \\
\hline Chowdi-2nd & 1183 & 4 & 0.87 & 4 & 2 & 20 & 1 & 2 & 1.46 & 60 & 0.176 \\
\hline Moolimane Nidagod & 1544.5 & 3 & 1.14 & 2 & 1 & 14 & 4 & 4 & 1.9 & 60 & 0.229 \\
\hline Manthaguli & 751 & 4 & 0.46 & 2 & 4 & 17 & 2 & 2 & 0.92 & 50 & 0.111 \\
\hline Belale & 2524.2 & 5 & 4.36 & 5 & 5 & 19 & 4 & 5 & 7.48 & 58 & 0.375 \\
\hline Basavana & 3808.5 & 5 & 4.7 & 3 & 4 & 18 & 5 & 4 & 9.41 & 50 & 0.565 \\
\hline Shindigere & 2150 & 3 & 1.85 & 4 & 2 & 9 & 2 & 1 & 3.71 & 50 & 0.319 \\
\hline
\end{tabular}


Table 3. Cont.

\begin{tabular}{|c|c|c|c|c|c|c|c|c|c|c|c|}
\hline Tanks & $\begin{array}{l}\text { Surface } \\
\text { Area } \\
\left(\mathrm{m}^{2}\right)\end{array}$ & $\begin{array}{c}\text { Tank } \\
\text { Condition }\end{array}$ & $\begin{array}{c}\text { Water- } \\
\text { Holding } \\
\text { Capacity } \\
\text { (Acre-foot) }\end{array}$ & $\begin{array}{l}\text { Vegetation } \\
\text { Health }\end{array}$ & $\begin{array}{l}\text { Wildlife } \\
\text { Habitat } \\
\text { Health }\end{array}$ & $\begin{array}{l}\text { Potential } \\
\text { Acreage } \\
\text { Irrigated }\end{array}$ & $\begin{array}{c}\text { Access } \\
\text { and } \\
\text { Convenience }\end{array}$ & Usability & $\begin{array}{l}\text { Potential } \\
\text { Storage } \\
\text { (Acre-foot) }\end{array}$ & $\begin{array}{c}\text { Ratio of } \\
\text { Current to } \\
\text { Potential } \\
\text { Storage (\%) }\end{array}$ & 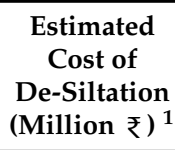 \\
\hline Hanmanth Devara & 5733.4 & 5 & 7.08 & 5 & 5 & 6 & 3 & 4 & 14.16 & 50 & 0.851 \\
\hline Bekkina Jaddi & 849.8 & 2 & 0.52 & 4 & 2 & 11 & 2 & 1 & 1.05 & 50 & 0.126 \\
\hline $\begin{array}{l}\text { Kelagima } \\
\text { Bommanalli }\end{array}$ & 69.9 & 2 & 0.03 & 3 & 1 & 11 & 1 & 1 & 0.06 & 50 & 0.010 \\
\hline Kadave-1st & 1352.9 & 3 & 2.5 & 3 & 2 & 44 & 2 & 2 & 4.01 & 62 & 0.201 \\
\hline Kadave-2nd & 345.8 & 2 & 0.17 & 4 & 2 & 25 & 5 & 1 & 0.34 & 50 & 0.051 \\
\hline Konkana & 1588.7 & 4 & 0.78 & 4 & 3 & 14 & 3 & 2 & 1.17 & 67 & 0.236 \\
\hline Golikoppa & 1635.1 & 3 & 1.21 & 5 & 3 & 41 & 5 & 4 & 2.42 & 50 & 0.243 \\
\hline Ashisara & 1187.9 & 2 & 1.46 & 2 & 1 & 23 & 2 & 4 & 2.93 & 50 & 0.176 \\
\hline Dalavaayi & 2160.8 & 3 & 1.6 & 4 & 4 & 40 & 4 & 4 & 3.2 & 50 & 0.321 \\
\hline
\end{tabular}

${ }^{1}$ Based on the assumption that $70 \%$ of the potential storage capacity of the tank needs to be de-silted. One ₹ (rupee) = US \$ 0.0147 in 2018. 
The tanks in the study area were used for irrigating rice paddy, areca nut, and coconut, as well as other crops grown within the orchard such as black pepper, banana, and sugarcane. However, the status of most of the irrigation tanks was overwhelmingly poor at the time of our field observation. Key informants expressed that overall tank performance had been on a progressive decline in virtually all the attributes that were studied. About $82 \%$ of the tanks were affected by water shortage. About $37 \%$ of the tanks had been restored in the last couple of decades in some form or the other. In three instances, local households had invested up to ₹ 500,000 (one ₹ (rupee) = US \$ 0.0147 in 2018) of their funds to restore the tanks. Four of the tanks had completely dried up in 2016 for their first time in history. Furthermore, $75 \%$ of the tanks had a significant buildup of silt and debris that negatively affected their storage potential.

The alternative uses for the tanks were reported to be primarily for wildlife habitat, along with fishing and washing animals to a lesser extent. Some farmers were interested in investing capital costs to implement small-scale fisheries for supplemental income but were discouraged by the currently available water resources and conditions of these tanks. The deteriorated tanks had also been resulting in increased wildlife presence on farms affecting the produce and thus resulting in less profit for the farmers. The need for the development of restoration management for these tanks was obvious and consistent throughout the study area.

The indicator values show how each individual tank attribute affected the overall performance of each tank. For the tank condition attribute, about $70 \%$ of the tanks received a score lower than a three on the qualitative scale of 1 to 10. Furthermore, the buildup of debris, sediment, and vegetation affected the water-holding capacity attribute, resulting in less volume of storm runoff captured by the tanks. Almost $50 \%$ of the tanks had a higher amount of debris that would not allow for the tank to capture as much of the rainfall in the monsoon season compared to its potential capacity. However, this did not affect the value of the potential storage indicator, for this indicator was measured by the potential for the tank to capture water after restoration. The tanks with larger size and depth were given a higher quantitative value for potential storage.

For vegetation and wildlife habitat health, many of the irrigation tanks were surrounded by agricultural land, which therefore would not allow for a diverse potential for native flora and fauna to prosper. About $40 \%$ of all tanks received a score of less than three on the qualitative scale for these two indicators. The access and convenience along with alternative usability indicators focus more heavily on the socio-economic aspect of the tanks. Sixty percent of the tanks were more than 500 meters off the road, usually surrounded by either dense forest land or areca orchard. This makes it difficult to reach for laborers and heavy machinery necessary to restore functions, as well as to access the tanks for non-agriculture uses. More than $70 \%$ of the tanks were given a score higher than a three for usability on the qualitative scale, and many of the farmers were interested in taking advantage of alternative production sources in the event of restoration. Most tanks had very diverse characteristics, making each one unique to its village location along with the agricultural community.

\subsection{Ranking of Irrigation Tanks}

As far as the weights of different indicators, it was evident that the stakeholders placed the most importance on those attributes that represented the importance of tanks for crop production. A weight of $33.3 \%$ was given to potential storage, $26.1 \%$ to tank condition, and $17.4 \%$ to water-holding capacity. This unsurprising result was reflective of the predominance of agriculture present in the study area, which supported most of the population. The attributes that signified ecological processes indicators scored lower weights (vegetation health $=5.5 \%$, wildlife habitat health $=6.7 \%$ ), although they were still significant to the overall ecosystem health of the area.

Interestingly, the indicator of crop area irrigated did not receive a high rank. Note that farmers were not allowed to directly extract water from tanks individually, and therefore, 
the indicator value of the total crop area irrigated may not have received high weightage. However, they seemed to emphasize the total water-holding potential of tanks which would ultimately increase the water available for agriculture, for instance, via groundwater recharge.

Table 4 presents the ranking of irrigation tanks in the study area based on the AHPsupported composite sustainability index (In). We grouped the tanks into four categories (i) Highly Sustainable (with $I n>75$ ), (ii) Sustainable ( $I n=51$ to 75), (iii) Less Sustainable (In $=26$ to 50), and (iv) Least Sustainable ( $I n<0$ to 25). Accordingly, Targod (97), Jaanamaki (78), and Kathlehalla (77) tanks rank in the top three and fall under the category of Highly Sustainable at the current time. The overall costs of restoring these three tanks were estimated at ₹ 4.5 million, and the total crop area to supported was 115 acres. Six tanks in the study area fell under the Moderately Sustainable category with a total cost of restoration of ₹ 3.4 million and a supported crop area of 89 acres. The majority of the tanks (21 out of 40) fell under the category of Less Sustainable, with a total restoration cost of ₹ 5.3 million and 468 acres of supported cropland. Lastly, eleven tanks ranked in the Least Sustainable category and would cost ₹ 1.6 million to restore; a cut could potentially irrigate 152 acres of crop. The district and state resource agencies may consider this priority list for prioritizing restoration funding decisions.

Table 4. Ranking of irrigation tanks based on Composite Sustainability Index (I_n) and their restoration costs.

\begin{tabular}{|c|c|c|c|}
\hline $\begin{array}{c}\text { Tank Sustainability Category } \\
\text { (Composite Sustainability } \\
\text { Score) }\end{array}$ & $\begin{array}{c}\text { Tank } \\
\text { (Composite Sustainability Index) }\end{array}$ & $\begin{array}{l}\text { Total Irrigated Area } \\
\text { Supported (acre) }\end{array}$ & $\begin{array}{l}\text { Cost of Restoration of All } \\
\text { Tanks in the Category }(₹) \\
\text { (Cost in ₹ per Acre of } \\
\text { Area Irrigated) }{ }^{1}\end{array}$ \\
\hline Highly sustainable (Above 75) & $\begin{array}{c}\text { Targod (97), Jaanamaki (78), } \\
\text { Kathlehalla (77) }\end{array}$ & 115 & $\begin{array}{c}4,548,392 \\
(39,551)\end{array}$ \\
\hline $\begin{array}{l}\text { Moderately sustainable } \\
\text { (51 to } 75)\end{array}$ & $\begin{array}{c}\text { Hanmanth Devara (62), Belale (56), } \\
\text { Ambalike (55), Basavana (55), } \\
\text { Appurayanajaddi (52), Devari Keri (51) }\end{array}$ & 89 & $\begin{array}{c}3,433,711 \\
(38,581)\end{array}$ \\
\hline $\begin{array}{l}\text { Less sustainable } \\
\qquad(26 \text { to } 50)\end{array}$ & $\begin{array}{l}\text { Emme (48), Ashimane (44), Bommanalli } \\
\text { (43), Bugadimane (41), Nagarakura (39), } \\
\text { Kibbali (36), Golikoppa (35), Dalavaayi } \\
\text { (35), Keshinamane (35), Halige (34), } \\
\text { Keresara (33), Konkana (33), Manthaguli } \\
\text { (30), Chowdi-2nd (29), Chowdi-1st (29), } \\
\text { Kadave-1st (28), Beerala (27), Nidagod } \\
\text { (27), Hakkimane-1st (27), Shindigere (26), } \\
\text { Anchigadde (26) }\end{array}$ & 468 & $\begin{array}{c}5,345,900 \\
(11,423)\end{array}$ \\
\hline $\begin{array}{l}\text { Least sustainable } \\
\text { (Less than 25) }\end{array}$ & $\begin{array}{c}\text { Moolimane Nidagod (24), } \\
\text { Hakkimane-2nd (23), Mulukina Koppa } \\
\text { (22), Malenalli (22), Kadave-2nd (20), } \\
\text { Arsapura (18), Ashisara (16), Bekkina } \\
\text { Jaddi (16), Gadigehole (10), Kelagima } \\
\text { Bommanalli (10) }\end{array}$ & 152 & $\begin{array}{c}1,645,342 \\
(10,825)\end{array}$ \\
\hline
\end{tabular}

As mentioned earlier, stakeholders placed high significance on attributes that represented the importance of tanks for crop production (weight of 33.3\% potential storage + $26.1 \%$ on tank condition $+17.4 \%$ to water-holding capacity). Therefore, we computed the average cost of restoration per acre of cropland irrigation that the restored tanks would support (Table 4). Interestingly, the unit costs of restoration were the highest at ₹ 39,551/acre for tanks under the Highly Sustainable category, followed by Moderately Sustainable category ( ₹ 38,581), Less Sustainable ( ₹ 11,423), and Least Sustainable ( ₹ 10,825). That is, those tanks which ranked in the two higher Sustainability categories also had a higher price tag as they did have high overall sustainability performance values. 


\subsection{Household Water Use and Perception}

Of the 200 respondents, 174 farmers had areca nut, 150 dairy animals, 56 rice paddy, and 12 sugarcane. Furthermore, a total of approximately 170,000 liters of water was consumed per day for all respondents for both household and agricultural use, with an average individual household use of 954 liters. The main source of this water was through captured rainfall, on which $78 \%$ of the respondents were dependent. On the question of water scarcity, $67 \%$ of respondents felt the current water availability was insufficient to reach their household/agricultural needs, with the highest record of insufficient water resources in 2017. The majority of the respondents attributed the water scarcity impacts to a decline in natural vegetation as well as rainfall during both the pre- and post-monsoon season. This scarcity had led to detrimental impacts on farmland, with $60 \%$ of respondents suffering from greater than 30\% loss of crop yields in 2017.

Farmers were partially dealing with the water shortage through investments into alternative sources of irrigation. About $45 \%$ of the respondents had either drip or sprinkler irrigation for their areca nut orchard, with the remaining $55 \%$ of the respondents interested in irrigation infrastructure but did not have the necessary funds. The respondents were dependent on rainfall not only for sheet flow but also to recharge the groundwater wells, as $100 \%$ of the respondents used open wells as their primary source of household water. Ninety percent of the bore wells that were constructed in the last five years had run dry, and as a result, less than $20 \%$ of the respondents only expressed interest in personal investments for water resources.

We analyzed farmers' perception of the lift irrigation project proposed by the State Minor Irrigation Department. Surprisingly, only $48 \%$ of respondents were aware of the proposed project prior. However, $78 \%$ of the respondents supported the lift irrigation project. There were a multitude of benefits that respondents believed they would experience if the lift irrigation project was constructed. These benefits included a cooler climate, healthier environmental conditions, natural forest growth, an increase in the wildlife population, and higher agricultural yields. However, respondents did have some general concerns with the project to a certain extent. About $12 \%$ opposed the project, as they did not have trust in the government to properly allocate funds and believed that the de-siltation and maintenance of the current irrigation tanks should be prioritized. In the event that the lift irrigation project would not materialize, more than half the respondents said they might consider more bore wells, groundwater recharge facilities, and rooftop rainwater harvesting structures. About $45 \%$ of the respondents had no personal future investment plans, and $15 \%$ expressed the need to migrate out.

\subsection{Analysis of the Lift Irrigation Project}

The proposed lift irrigation project is expected to bring several direct and indirect benefits to the local communities. Table 5 presents the sample average values of land area, annual agriculture water use, and gross income from different agricultural activities. The sample households operated an average land area of 2.88 acres and consumed an average of 29,281 thousand liters of water for agricultural purposes each year. It was evident that areca nut and pepper were the two dominant crops that contributed the most to the household agriculture income.

Table 6 shows the results of the estimated coefficients of the trans-log Cobb-Douglas household agricultural revenue function. We estimated the model, with and without the intercept and the later model gave better results. The adjusted $R^{2}$ value, the measure of goodness of fit, was 0.98. Examining the residual error plots of the model revealed no discernible pattern, indicating the error term had constant variance across the observed values [65]. The model coefficients were statistically significant and had the right signs. Both water and land positively influenced household agriculture revenue. Notice that the estimated coefficients of water consumption and land variables (0.5176 and 0.2320, respectively) are the direct estimates of the water and land elasticities of agriculture revenue, 
representing $51.76 \%$ and $23.20 \%$ increase in the household revenue, respectively, as a result of a 100 percent LIS-induced increase in water consumption and crop area, respectively.

Table 5. Average farm size, agricultural water use, and gross revenue from agricultural production for the sample households, 2018.

\begin{tabular}{cc}
\hline Variable & Amount \\
\hline Farm size (acre/household) & 2.88 \\
Water Consumption ('000 liter/household/year) & 29,281 \\
Annual Gross Revenue (₹/household) ${ }^{1}$ : & \\
Areca nut & 711,174 \\
Pepper & 138,078 \\
Banana & 14,323 \\
Coconut (in orchard) & 21,852 \\
Rice paddy & 6756 \\
Coconut (out of orchard) & 16,723 \\
Sugarcane & 4531 \\
Dairy & 47,049 \\
Total & 960,486 \\
\hline
\end{tabular}

${ }^{1}$ One ₹ (Rupee) = US \$ 0.0147 in 2018.

Table 6. Estimated trans-log Cobb-Douglas model of household agricultural revenue.

\begin{tabular}{ccc}
\hline Variable & Co-Efficient & $p$-Value \\
\hline Water consumption (‘000 liter) & 0.5176 & 0.00 \\
Household land size (acre) & 0.2320 & 0.00 \\
Areca dummy & 1.5121 & 0.00 \\
Adjusted $R^{2}$ & 0.98 & \\
$N$ & 200 & \\
\hline
\end{tabular}

The next step in estimating the incremental benefits of the lift irrigation project was to determine the additional water that would become available from the proposed project. Based on the sample average annual water use per acre and the total crop area in the tentank command area, the total annual water consumption was estimated at 1727 thousand $\mathrm{m}^{3}$, which was only about $19.4 \%$ of the total annual runoff of 8888 thousand $\mathrm{m}^{3}$ contributed by the ten-tank catchment area, and $1.8 \%$ of the total annual runoff of 94,158 thousand $\mathrm{m}^{3}$ generated across the entire Bhairumbe and Targod panchayat area.

For the purpose of this analysis, we considered three scenarios of water-use increase, i.e., $50 \%, 75 \%$, and $100 \%$ net increase from the current use level of 1727 thousand $\mathrm{m}^{3}$ to 2591 thousand $\mathrm{m}^{3}, 3022$ thousand $\mathrm{m}^{3}$, and 3454 thousand $\mathrm{m}^{3}$, respectively. Note that the actual water extraction amounts (in $\mathrm{m}^{3} 2467,3101$, and 4317 , respectively) need to be more than the above net increase amounts in order to account for about $30 \%$ loss due to evaporation and seepage. These actual extraction amounts were within the total annual runoff of the ten-tank catchment area of 8888 thousand $\mathrm{m}^{3}$. Additionally, the tanks were state-owned, and therefore, farmers may not be able to directly extract water delivered to project tanks. Nevertheless, we assumed that increasing the water level in the tanks during the dry season would proportionately increase the water table in wells and flows in open streams in the command area. However, as mentioned before, only $45 \%$ of the growers had modern irrigation technology, making use of the groundwater. To make full use of the increased water availability from the LIS, it is necessary for the remaining farmers to invest in irrigation technology. Therefore, in the benefit-cost analysis, we did include this additional capital expenditure.

The ten-tank area's gross agricultural revenue without the project was ₹ 49.50 million. Table 7 gives Monte Carlo simulation estimates of the nine gross revenue amounts provided through incremental water delivery $(50 \%, 75 \%$, and $100 \%)$ and without any increase in cropland. In addition, presented below are the net farmers' income and labor income that could be potentially realized under alternative water availability scenarios 
Table 7. Expected annual increase in farmers' and agricultural laborers' income under alternative water increase scenarios in the ten-tank command area (with no expansion in crop area).

\begin{tabular}{ccc}
\hline \multirow{2}{*}{ Water Increase Scenario } & \multicolumn{2}{c}{ Increase in Agriculture Revenue and Incomes } \\
\cline { 2 - 3 } & Mean (₹ million) ${ }^{\mathbf{1}}$ & SD \\
\hline & Incremental Gross Agriculture Income & 0.28 \\
$50 \%$ Increase & 12.88 & 0.41 \\
$75 \%$ Increase & 19.32 & 0.55 \\
$100 \%$ Increase & 25.76 & 0.14 \\
& Incremental Net Agriculture Income \\
& $(\sim 45 \%$ of the Gross Incremental Income) \\
$50 \%$ Increase & 5.80 & 0.21 \\
$75 \%$ Increase & 8.70 & 0.28 \\
$100 \%$ Increase & 11.60 & 0.07 \\
& \multicolumn{2}{c}{ Incremental Labor Income } \\
$50 \%$ Increase & $(\sim 20 \%$ of the Gross Incremental Income) \\
$75 \%$ Increase & 2.90 & 0.10 \\
$100 \%$ Increase & 4.35 & 0.14 \\
\hline
\end{tabular}

${ }^{1}$ One ₹ (Rupee) = US \$ 0.0147 in 2018.

The project was expected to increase the annual gross agriculture income by an average of ₹ 12.88 million ( $26.0 \%$ increase from the current level) under a $50 \%$ water increase scenario, and by an average of ₹ 25.76 million $(52.0 \%$ increase from the current level) under the $100 \%$ water increase scenario. The expected increase in the annual net farmers' income was ₹ 5.80 million under the $50 \%$ water increase scenario and ₹ 11.60 million under the $100 \%$ water increase scenario. Similarly, the annual increase in labor income was ₹ 2.90 million and ₹ 5.80 million, respectively.

Some farmers in the study area did own pastureland. When asked in the household survey if, with increased irrigation potential, farmers would convert pasture to cropland, $82.14 \%$ of farmers expressed interest in doing so. They would likely grow areca nut, coconut, and other crops on the converted land. We, therefore, conducted the Monte Carlo benefitcost analysis for two additional scenarios to represent a possible expansion of cropland if the proposed project would materialize. The project benefits are largely dependent on the type of crops grown in the command area. According to the key informants, the ten-tank project command area had one of the best areca nut and pepper production yields in the entire Uttara Kannada district. The majority of the cropland in this command area was under the above two high-value crops. Based on our primary survey and discussion with stakeholders, if more water became available, farmers would likely expand their cropland eventually. Based on the sample average percent distribution of croplands of an average household, we estimated the total pastureland in the ten-tank area at about 82.14 acres. Multiplying this number by $82 \%$ (i.e., percent of respondents who expressed interest in land conversion), we arrived at 67.36 acres of potential crop area expansion. We adapted a third, more conservative scenario under which only half of the 82.14 acres of pastureland would be converted to crops. Furthermore, we included the usual costs of the establishment (from 4 to 15 years), annual maintenance and operating costs, and annual interest on loans for the introduced cropland in the two land-conversion scenarios.

Table 8 presents the values of BCR, NPV, and PBP for the nine project scenarios (combination of water and cropland area increase). Figure $3 a, b$ presents the NPV distributions for selected water-use-land-conversion scenarios. With BCR being less than 1.0, the project was found to be not economically viable with a $50 \%$ increase in water supply, irrespective of the level of bena land conversion (50W-00L, 50W-50L, and 50W-82L scenarios). The project emerged to be economically viable with a $75 \%$ and $100 \%$ water increase and all three scenarios of land conversion. The only exception was scenario $75 \mathrm{~W}-50 \mathrm{~L}$ where the $\mathrm{BCR}$ was 0.99 . For the rest of the water-land scenarios, the BCR ranged from a low of 1.23 (100W-50L) to 1.73 (100W-00L). 
Table 8. Monte Carlo simulation estimates of mean and standard deviation values of Benefit-Cost Ratios, Net Present Values, and Pay-back Period for the lift irrigation scheme under alternative water delivery and land-conversion scenarios.

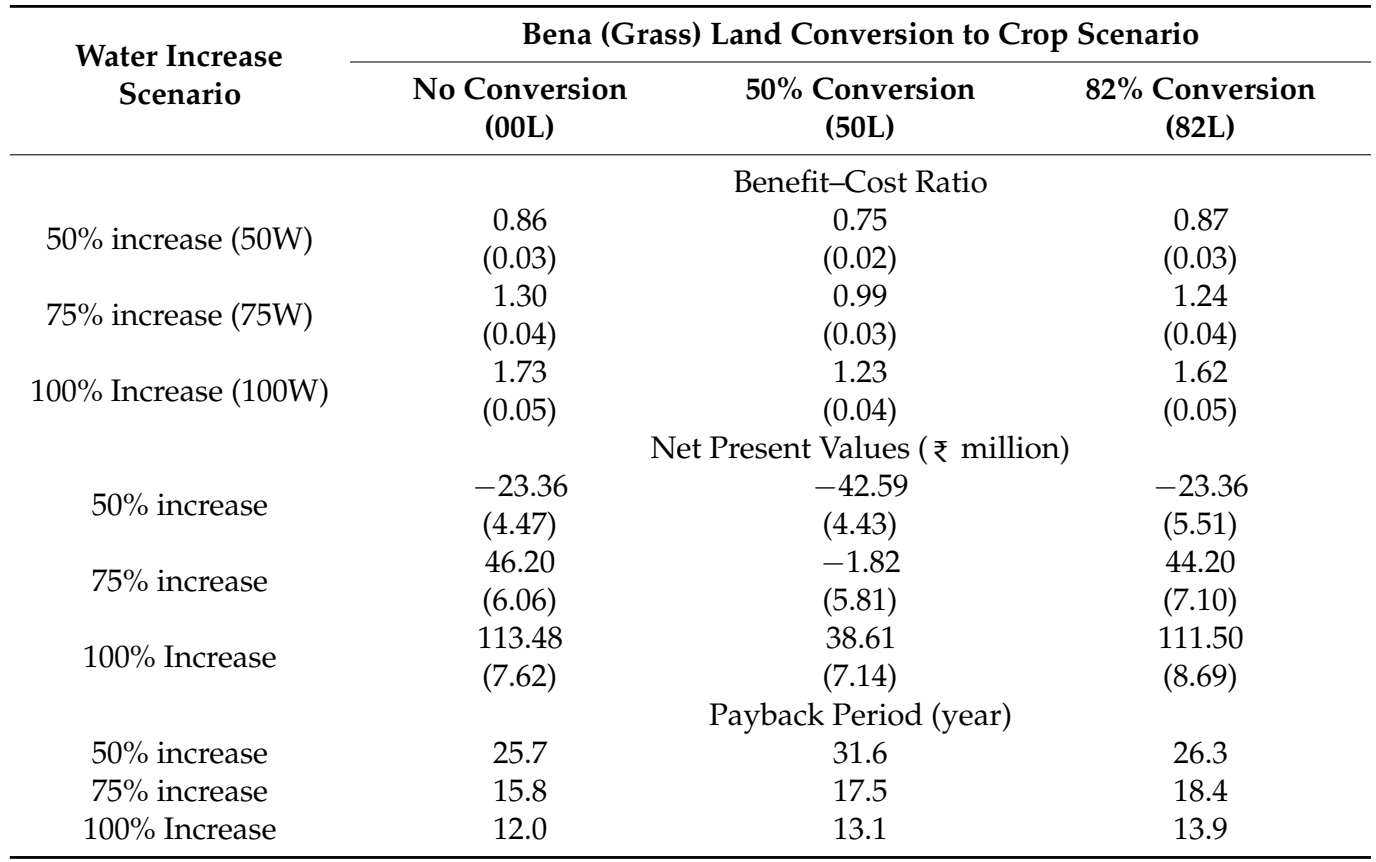

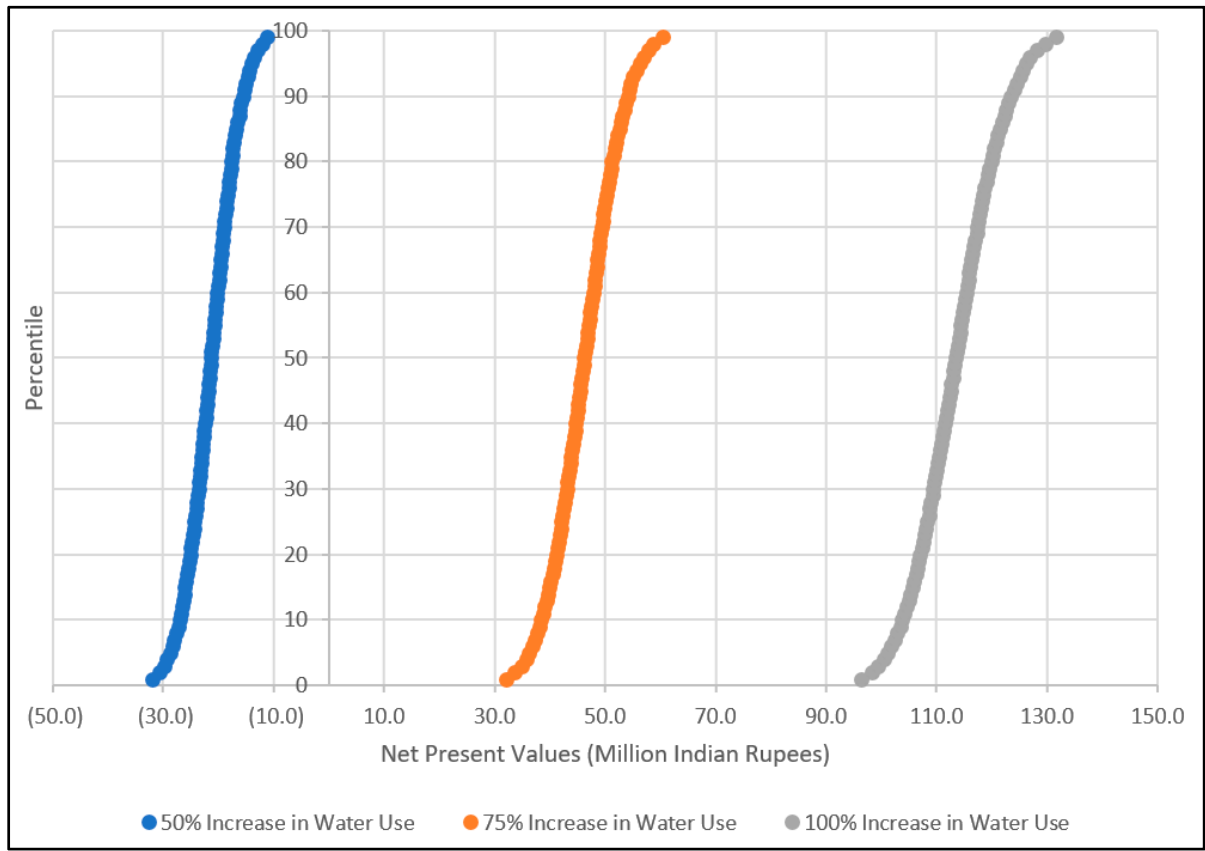

(a)

Figure 3. Cont. 


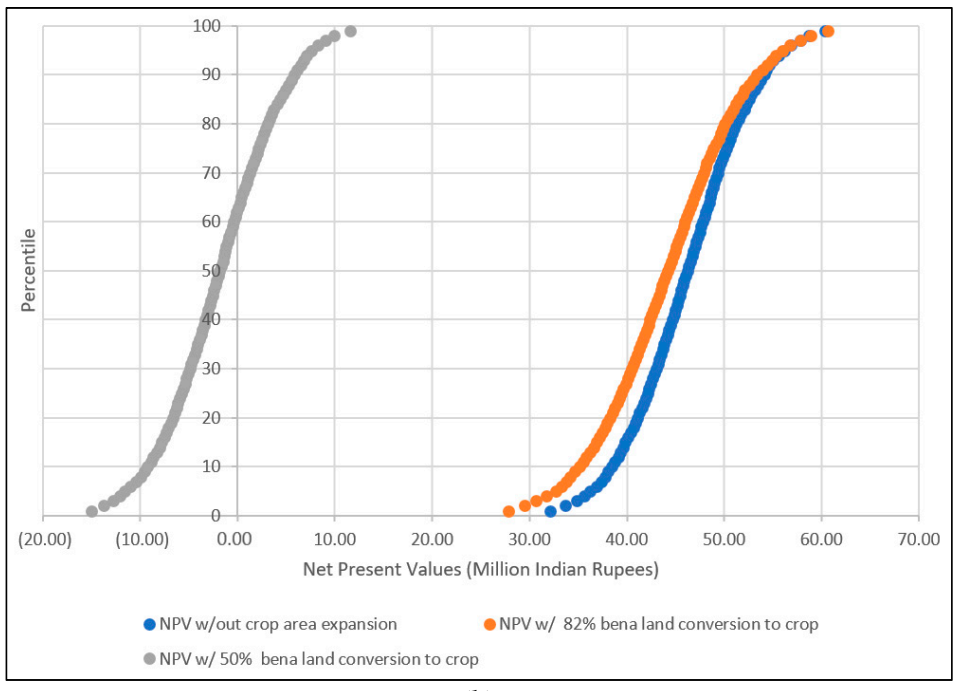

(b)

Figure 3. Net present value distributions of the lift irrigation project under alternative water use increase and land-conversion scenarios (generated from 5000 runs each); (a) increase in water consumption $(50 \%, 75 \%$, and $100 \%)$ with no change in crop area: NPVs for $75 \%$ and $100 \%$ water increases were positive in $100 \%$ of the simulation runs; and (b) bena land conversion $(0 \%, 50 \%$, and $82 \%$ ) and increase in water consumption by $75 \%$ : NPVs with no crop area expansion and $82 \%$ bena land conversion were positive and almost identical in $100 \%$ of the simulation runs.

Average NPVs followed similar trends across all the project scenarios. Two important results are noteworthy. First, NPVs for the 50\% water increase were negative under all three land-conversion scenarios. As presented in Figure 3a, the NPV percentile distribution for 50W-00L (50\% water increase and zero land conversion) generated from the 5000 Monte Carlo runs indicates that there is a $100 \%$ chance that the project would be economically not viable under this scenario. The incremental net household income and labor income under the $50 \%$ water increase scenario were not high enough to offset the increased cost of the lift irrigation project, new irrigation technology, and land conversion. Second, NPVs of 0\% and $82 \%$ land conversion were fairly close to each other for all water increase scenarios [Table 8 and Figure 3b]. Under all three water increase scenarios, the NPVs with 50\% land conversion were either negative or significantly lower than NPVs of the no-land conversion and $82 \%$ land-conversion scenario. NPVs without converting the bena land were the highest of all the three land-conversion scenarios. This clearly supports the view that because of the high costs of land conversion and irrigation infrastructure, expanding cropland because of additional water availability may not necessarily be viable. The new cropland will compete with the existing cropland for water.

Table 8 also presents PBP for all project scenarios. The $100 \%$ water increase scenario had the shortest PPB of 12-14 years, while the 50\% water increase scenario had the longest PPB of 25-32 years. However, although the initial investments under the 50\% water increase scenarios would be recovered, their overall project BCRs were less than 1.0, and therefore, the project would not be economically viable.

Finally, the Monte Carlo analysis considered the effects of a host of hydrological, production, and economic uncertainty factors on the project performance. These factors included the production risks embedded in the agricultural revenue function (i.e., the productivities of water and land), annual net profits, costs of production including labor, and annual operating costs of lift irrigation scheme and irrigation infrastructure. We also considered the sensitivity of the project performance to various levels of incremental water availability and land-conversion rates. Even with the multiple sources of uncertainty conditions, the proposed LIS would be economically viable as long as the same would deliver about $75 \%$ or more water for the area. It is important to note that the above assertion holds true even without considering other tangible and non-tangible benefits of the project. 


\section{IWRM Implications and Conclusion}

The methodological framework and results of this study enable decisionmakers and stakeholders to consider multiple attributes of irrigation tanks simultaneously while implementing programs for modernizing existing irrigation tanks. This framework captures the general sustainability principles of local IWRM of water-use efficiency, equity, hydroecological balance, and stakeholder involvement. This study analyzed primarily two approaches to enhancing agricultural tanks in rural India: (a) de-silting existing tanks and (b) stocking tanks through a lift irrigation scheme. While irrigation is the key variable in the assessment of irrigation tanks, other output values, such as benefits to social forestry, fisheries, livestock, and native species, may be considered. The study region produces a large percent of runoff water which can be partially captured by traditional irrigation tanks, provided they are managed well. Such an effort would not only increase the overall income for agricultural households, farmworkers, and other users that use these tanks for allied activities but would also improve the overall ecosystem health of the watershed.

Responsibility for restoring and maintaining irrigation tanks rests with a variety of stakeholders and institutions, most notably the local, district, and state government agencies. The allocated budget for tank restoration depends on the demands of elected members and the availability from the total budget of the district agency. The scientific and stakeholder-informed approach developed in this study could help the above agencies make more objective decisions concerning budget allocation for tank restoration. Using our analysis framework, we pointed out several instances where tanks had a high potential for increasing rural agricultural and farmworkers' incomes yet were in poor operational condition. There is ample scope for improving such tanks and maximizing overall IWRM sustainability goals. Additionally, we found that some of the tanks with a high composite sustainability index also had high costs of restoration on a per acre basis of potential irrigation. When costs become a limiting factor, the agencies may want to prioritize tanks on the list with the next best sustainability score and lower restoration cost. Properly planned lift irrigation schemes can enrich existing tanks and improve irrigation during the dry season. In the study area, there was a strong desire for large- and small-scale irrigation infrastructure and management. Based on the benefit-cost analysis, we found the proposed project along the Shalmala river to be economically viable if the water availability increased at least by about $75 \%$ from the current use level.

The study results have several implications for the local-IWRM implementation. First, from an environmental point of view, the proposed restoration measures could enhance water availability and attendant ecological benefits in the study region if the minor irrigation tanks are restored in a timely fashion. Increasing the stock of water through LIS remains within the overall natural hydrological limits of the region. However, without increasing the storage capacity of the existing tanks to capture LIS-generated additional water, the benefits of LIS may not fully realize.

Second, from the point of efficiency, the economic viability of the local IWRM projects depends on several socio-economic factors and hydrological and other environmental characteristics of the area [66]. Based on the household survey, it was evident that as many as $82 \%$ of farmers were eager to expand their crop area when new water would become available. Our analysis shows that crop area expansion comes at high establishment costs and could compete for water with already-existing cropland. Using the incremental water ( $75 \%$ or more) on existing cropland could be just as profitable as the crop area expansion. The land conversion is a private decision, and those farmers who have private grassland may exercise their right to convert the same in response to increased water availability from the project. This could easily lead to the classic case of the "tragedy of the commons" [67] and put pressure on a publicly funded common water resource. Avoiding such problems in the future would require suitable education, outreach, and regulatory measures for farmers so that crop area expansion is limited to low-water-intensive and least expensive crops.

Third, from an equity point of view, only half of the farmers in the study area are currently equipped with irrigation technology and private irrigation wells. The proposed 
LIS would not be even economically viable without increasing the irrigation capacity of the remaining farmers. Therefore, it makes both equity and economic sense to empower those farmers with proper irrigation facilities. That would probably require increasing their access to credit institutions and providing suitable outreach and training.

Fourth, the above issues also point to other important local-IWRM principles of stakeholder participation and coordinated governance. The benefits of proposed rank restoration and water enhancement through LIS cannot be realized if the community is not made part of the decisionmaking [66]. Local water user associations may want to take a pro-active role in providing inputs to district and state agencies on how and which tanks get prioritized in a timely fashion, how the restored tanks get utilized for multiple uses (agriculture, environmental, and household), and new crop area expansion.

Finally, the probabilistic benefit-cost analysis considered only the agricultural sector benefits which were easiest to quantify, while there could be offsite costs and benefits of the project [68] or broader environmental and socio-economic effects outside of the project's command and catchment areas. Further studies on watershed management projects could look at additional measures for economic viability, social desirability, and ecological impacts on broader regions.

Author Contributions: Conceptualization, survey design, data analysis, original draft writing: N.C. and M.G.B.; data collection: N.C.; manuscript reviewing, editing, and suggestions: all authors; funding acquisition: M.G.B.; field-level networking with key informants: K.M.H., G.V.H. and R.B. All authors have read and agreed to the published version of the manuscript.

Funding: This research was funded by the National Science Foundation, grant number EAR-1204762 and USDA NIFA grant number 2016-38422-25549.

Institutional Review Board Statement: The study was conducted according to the guidelines of the Declaration of Helsinki, and approved by Institutional Review Board of the Florida International University (protocol code IRB-18-0021 and 11 January 2018).

Informed Consent Statement: Informed consent was obtained from all subjects involved in the study.

Data Availability Statement: The individual household data relating to socio-economic aspects presented in this study are available on request from the corresponding author. The data are not publicly available due to privacy reason. The landuse, elevation data and soil classification data were obtained from the India's National Remote Sensing Center (https:/ / www.nrsc.gov.in/, accessed on 1 February 2018) and the Indian National Bureau of Soil Survey (https: / www.nbsslup.in/aboutinstitute.html, accessed on 1 February 2018). Restrictions may apply to the availability of these data.

Acknowledgments: The authors gratefully acknowledge the helpful assistance received from Gopalakrishna Hegde, Shashikanth Hegde, G. M. Hegde, and Vikas Naik during the primary and secondary data collection. Also, thanks to Ramachandra. G. Bhat, Bhaskar Bhat, Amit Hegde, Niranjan Bhat, and Amruta Bhat for their assistance during the fieldwork. We also thank Daniel Gann for advice on the mapping of land and crop cover and Assefa Melesse for technical advice during the study design. This is contribution number 1018 from the Southeast Environmental Research Center in the Institute of Environment at Florida International University.

Conflicts of Interest: The authors declare no conflict of interest.

\section{References}

1. World Economic Forum. Managing Our Future Water Needs for Agriculture, Industry, Human Health and the Environment; World Economic Forum Water Initiative: Geneva, Switzerland, 2009; p. 64.

2. UNDP. Human Development Report; United Nations Development Programme, 1 UN Plaza: New York, NY, USA, 2006 ; p. 440.

3. Cosgrove, W.J.; Loucks, D.P. Water management: Current and future challenges and research directions. Water Resour. Res. 2015, 51, 4823-4839. [CrossRef]

4. Lefore, N.; Giordano, M.; Ringler, C.; Barron, J. Sustainable and equitable growth in farmer-led irrigation in Sub-Saharan Africa: What will it take? Water Altern. 2019, 12, 156-168.

5. Balasubramanya, S.; Stifel, D. Viewpoint: Water, agriculture \& poverty in an era of climate change: Why do we know so little? Food Policy 2020, 93, 101905. [CrossRef]

6. Fulazzaky, M.A. Challenges of Integrated Water Resources Management in Indonesia. Water 2014, 6, 2000-2020. [CrossRef] 
7. Pérez-Sánchez, J.; Senent-Aparicio, J. Integrated water resources management on a local scale: A challenge for the user community-A case study in Southern Spain. Environ. Earth Sci. 2015, 74, 6097-6109. [CrossRef]

8. Hassing, J.; Ipsen, N.; Clausen, T.; Larsen, H.; Lindgaard-Jørgensen, P. Integrated Water Resources Management in Action; WWAP, DHI Water Policy, UNEP-DHI Centre for Water and Environment, United Nations Educational, Scientific and Cultural Organization: Paris, France, 2009; p. 22.

9. Hemamalini, J.; Mudgal, B.; Sophia, J. Sustainability of Tank Eco-systems from IWRM Perspective. Aquat. Procedia 2015, 4, 633-640. [CrossRef]

10. Goyal, V.C.; Garg, A.; Patil, J.P.; Thomas, T. Formulation of integrated water resources management (IWRM) plan at district level: A case study from Bundelkhand region of India. Hydrol. Res. 2020, 22, 52-69. [CrossRef]

11. Biswas, A.K. Integrated Water Resources Management: A reassessment. A water forum contribution. Water Int. 2004, 29, 248-256. [CrossRef]

12. Foster, S.; Ait-Kadi, M. Integrated Water Resources Management (IWRM): How does groundwater fit in? Hydrogeol. J. 2012, 20, 415-418. [CrossRef]

13. Wheeler, S.; Carmody, E.; Grafton, R.; Kingsford, R.; Zuo, A. The rebound effect on water extraction from subsidising irrigation infrastructure in Australia. Resour. Conserv. Recycl. 2020, 159, 104755. [CrossRef]

14. Freire-González, J. Does Water Efficiency Reduce Water Consumption? The Economy-Wide Water Rebound Effect. Water Resour. Manag. 2019, 33, 2191-2202. [CrossRef]

15. Moench, M. Allocating the Common Heritage: Debates over Water Rights and Governance Structures in India. Econ. Political Wkly. 1998, 33, A46-A53.

16. Pulido-Velazquez, D.; Garrote, L.; Andreu, J.; Martin-Carrasco, F.-J.; Iglesias, A. A methodology to diagnose the effect of climate change and to identify adaptive strategies to reduce its impacts in conjunctive-use systems at basin scale. J. Hydrol. 2011, 405, 110-122. [CrossRef]

17. Iglesias, A. Policy issues related to climate change in Spain. In Policy and Strategic Behavior in Water Resource Management; Dinar, A., Albiac, A., Eds.; Earthscan: London, UK, 2009.

18. Singh, K. Managing Common Pool Resources: Principles and Case Studies; Oxford University Press: New Delhi, India, $1994 ;$ p. 366.

19. Patil, K.R.; Chandrakanth, M.G.; Sadhana, H.S.; Olekar, J. Returns to Irrigation, Natural Resource Management, Research, and Extension. In Re-Visiting Agricultural Policies in the Light of Globalisation; Marothia, D., Martin, W., Janaiah, A., Dadhich, C.L., Eds.; Indian Society of Agricultural Economics: Mumbai, India, 2016; pp. 81-94.

20. Gómez-Alejandre, S.; De La Blanca, E.S.; De Usera, C.A.; Rey-Stolle, M.F.; Hernández-Fuentes, I. Partial specific volume of hyaluronic acid in different media and conditions. Int. J. Biol. Macromol. 2000, 27, 287-290. [CrossRef]

21. Arumugam, N.; Mohan, S.; Ramaprasad, R. Sustainable Development and Management of Tank Irrigation Systems in South India. Water Int. 1997, 22, 90-97. [CrossRef]

22. Sakthivadivel, R.; Gomathinayagam, P.; Shah, T. Rejuvenating Irrigation Tanks through Local Institutions. Econ. Political Wkly. 2004, 39, 3521-3526. [CrossRef]

23. Lipton, M.; Litchfield, J.; Faurès, J.M. The effects of irrigation on poverty: A framework for analysis. Water Policy 2003, 5, 413-427. [CrossRef]

24. Bassi, N.; Kumar, M.D.; Sharma, A.; Pardha-Saradhi, P. Status of wetlands in India: A review of extent, ecosystem benefits, threats and management strategies. J. Hydrol. Reg. Stud. 2014, 2, 1-19. [CrossRef]

25. Meher, R. Globalization, Displacement and the Livelihood Issues of Tribal and Agriculture Dependent Poor People: The Case of Mineral-based Industries in India. J. Dev. Soc. 2009, 25, 457-480. [CrossRef]

26. Anbumozhi, V.; Matsumoto, K.; Yamaji, E. Towards Improved Performance of Irrigation Tanks in Semi-Arid Regions of India: Modernization Opportunities and Challenges. Irrig. Drain. Syst. 2001, 15, 293-309. [CrossRef]

27. Shankari, U. Tanks: Major problems in minor irrigation. Econ. Political Wkly. 1991, 26, A115-A119, A122-A125. Available online: http:/ / www.jstor.org/stable/10.2307/41627025 (accessed on 1 February 2018).

28. Kalle, J.; Kasi, E. Lift Irrigation Schemes in Andhra Pradesh. South Asia Res. 2016, 36, 377-396. [CrossRef]

29. Agoramoorthy, G.; Chaudhary, S.; Hsu, M.J. Sustainable Development Using Small Dams An Approach to Avert Social Conflict and Relive Poverty in India's Semi-arid Regions. Asia Pac. J. Soc. Work. Dev. 2009, 19, 52-69. [CrossRef]

30. Reddy, V.R.; Reddy, M.S.; Palanisami, K. Tank rehabilitation in India: Review of experiences and strategies. Agric. Water Manag. 2018, 209, 32-43. [CrossRef]

31. Balasubramanian, R.; Govindasamy, R. Ranking irrigation tanks for modernization. Agric. Water Manag. 1991, $20,155-162$. [CrossRef]

32. Saaty, T.L. The Analytic Hierarchy Process; McGraw Hill International: New York, NY, USA, 1980.

33. Mavrommati, G.; Borsuk, M.; Howarth, R. A novel deliberative multicriteria evaluation approach to ecosystem service valuation. Ecol. Soc. 2017, 22. [CrossRef]

34. Seleman, A.; Bhat, M.G. Multi-criteria assessment of sanitation technologies in rural Tanzania: Implications for program implementation, health and socio-economic improvements. Technol. Soc. 2016, 46, 70-79. [CrossRef]

35. Krajnc, D.; Glavic, P. A model for integrated assessment of sustainable development. Resour. Conserv. Recycl. 2005, 43, 189-208. [CrossRef] 
36. Nawalawala, B.N. Water resource development and water conservation strategy in India. In Proceedings of the 17th ICID European Regional Conference on Irrigation and Drainage, Varna, Bulgaria, 16-22 May 1994; pp. 69-78.

37. Srivastava, D.; Rao, K.V.G.K.; Visvanatha, N.A. Planning and management of integrated water and agricultural management. Role of drainage and challenges in 21st century. In Proceedings of the Eighth ICID International Drainage Workshop, New Delhi, India, 31 January-4 February 2000; pp. 307-322.

38. Goel, A.; Kumar, R. Economic analysis of water harvesting in a mountainous watershed in India. Agric. Water Manag. 2005, 71, 257-266. [CrossRef]

39. Sishodia, R.; Shukla, S.; Wani, S.P.; Graham, W.D.; Jones, J.W. Future irrigation expansion outweigh groundwater recharge gains from climate change in semi-arid India. Sci. Total Environ. 2018, 635, 725-740. [CrossRef]

40. Taner, T. A Flow Channel with Nafion Membrane Material Design of Pem Fuel Cell. J. Therm. Eng. 2019, 5, 456-468. [CrossRef]

41. Taner, T.; Naqvi, S.A.H.; Ozkaymak, M. Techno-economic Analysis of a More Efficient Hydrogen Generation System Prototype: A Case Study of PEM Electrolyzer with Cr-C Coated SS304 Bipolar Plates. Fuel Cells 2019, 19, 19-26. [CrossRef]

42. Taner, T.; Sivrioglu, M. A techno-economic \& cost analysis of a turbine power plant: A case study for sugar plant. Renew. Sustain. Energy Rev. 2017, 78, 722-730. [CrossRef]

43. Yang, S.; Shen, L.; Hadi, M. Risk Analysis to Account for Uncertainty in Benefit-Cost Evaluations of Intelligent Transportation Systems. Transp. Res. Rec. J. Transp. Res. Board 2007, 2035, 187-194. [CrossRef]

44. Khazraeian, S.; Hadi, M. Monte Carlo Simulation-Based Benefit-Cost Analysis Combined with Analytical Hierarchy Process to Support ITS Investment with Consideration of Connected Vehicle Technology. Transp. Res. Rec. J. Transp. Res. Board 2018, 2672, 1-12. [CrossRef]

45. Sullivan, W.; Orr, R.G. Monte Carlo Simulation Analyzes Alternatives in Uncertain Economy. Ind. Eng. 1982, 14, $42-49$.

46. Boyle, P.P. Options: A Monte Carlo approach. J. Financ. Econ. 1977, 4, 323-338. [CrossRef]

47. Kerr, J. Watershed Development, Environmental Services, and Poverty Alleviation in India. World Dev. 2002, 30, 1387-1400. [CrossRef]

48. Helmut, J.G.; Lambin, E.F. Proximate Causes and Underlying Driving Forces of Tropical Deforestation. Biosci. ProQuest Biol. J. 2002, 52, 143-150.

49. Sundarapandian, S.; Swamy, P.S. Forest Ecosystem Structure and Composition Along an Altitudinal Gradient in the Western Ghats, South India. J. Trop. For. Sci. 2015, 12, 104-123.

50. USDA. Urban hydrology for small watersheds (PDF). In Technical Release 55 (TR-55), 2nd ed.; United States Department of Agriculture (USDA), Natural Resources Conservation Service, Conservation Engineering Division: Washington, DC, USA, 1986.

51. Pal, B.; Samanta, S. Surface runoff estimation and mapping using Remote Sensing and Geographic Information System. Int. J. Adv. Sci. Technol. 2011, 3, 106-114.

52. Muthu, A.C.L.; Santhi, M.H. Estimation of Surface Runoff Potential using SCS-CN Method Integrated with GIS. Indian J. Sci. Technol. 2015, 8. [CrossRef]

53. Charles, N. Assessment of Watersheds for Sustainable Agriculture in Karnataka, India. Master's Thesis, Earth and Environment Department, Florida International University, Miami, FL, USA, 2019.

54. Munasinghe, M. Towards Sustainable Development: The Role of Environmental Economics and Valuation (The World Bank Environment Paper Number 3); The World Bank: Washington, DC, USA, 1992.

55. Palanisami, K.; Flinn, J. Evaluating the performance of tank irrigation systems. Agric. Syst. 1988, 28, 161-177. [CrossRef]

56. Zekri, S.; Romero, C. Public and Private Compromises in Agricultural Water Management. J. Environ. Manag. 1993, 37, 281-290. [CrossRef]

57. Verma, M. Economic Valuation of Bhoj Wetland for Sustainable Use, Report Prepared for India: Environmental Management Capacity Building Technical Assistance Project; India Institute of Forest Management: Bhopal, India, 2001.

58. Elbarkouky, M.M.G. A Multi-Criteria Prioritization Framework (MCPF) to Assess Infrastructure Sustainability Objectives. J. Sustain. Dev. 2012, 5, 1. [CrossRef]

59. ESRI. ArcGIS Desktop: Release 10; Environmental Systems Research Institute: Redlands, CA, USA, 2018.

60. Rezaei, J. Best-worst multi-criteria decision-making method. Omega 2015, 53, 49-57. [CrossRef]

61. Odu, G. Weighting methods for multi-criteria decision making technique. J. Appl. Sci. Environ. Manag. 2019, 23, 1449. [CrossRef]

62. Cobb, C.W.; Douglas, P.H. A theory of production. Am. Econ. Rev. 1928, 18, 139-165.

63. Sau, R. Agricultural Revolution by Production Function. Econ. Political Wkly. 1971, 6, A50-A52, A54-A55, A57-A58. Available online: https: / / www.jstor.org/stable/4382196 (accessed on 30 June 2018).

64. Hayami, Y. Sources of Agricultural Productivity Gap Among Selected Countries. Am. J. Agric. Econ. 1969, 51, 564-575. [CrossRef]

65. Koenker, R.; Bassett, G. Robust Tests for Heteroscedasticity Based on Regression Quantiles. J. Econom. Soc. 1982, 50, 43. [CrossRef]

66. Atisa, G.; Bhat, M.G.; McClain, M.E. Economic Assessment of Best Management Practices in the Mara River Basin: Toward Implementing Payment for Watershed Services. Water Resour. Manag. 2014, 28, 1751-1766. [CrossRef]

67. Hardin, G. The Tragedy of the Commons. Science 1968, 162, 1243-1248. [CrossRef] [PubMed]

68. Ninan, K.N.; Lakshmikanthamma, S. Social Cost-benefit Analysis of a Watershed Development Project in Karnataka, India. Ambio 2001, 30, 157-161. [CrossRef] [PubMed] 